
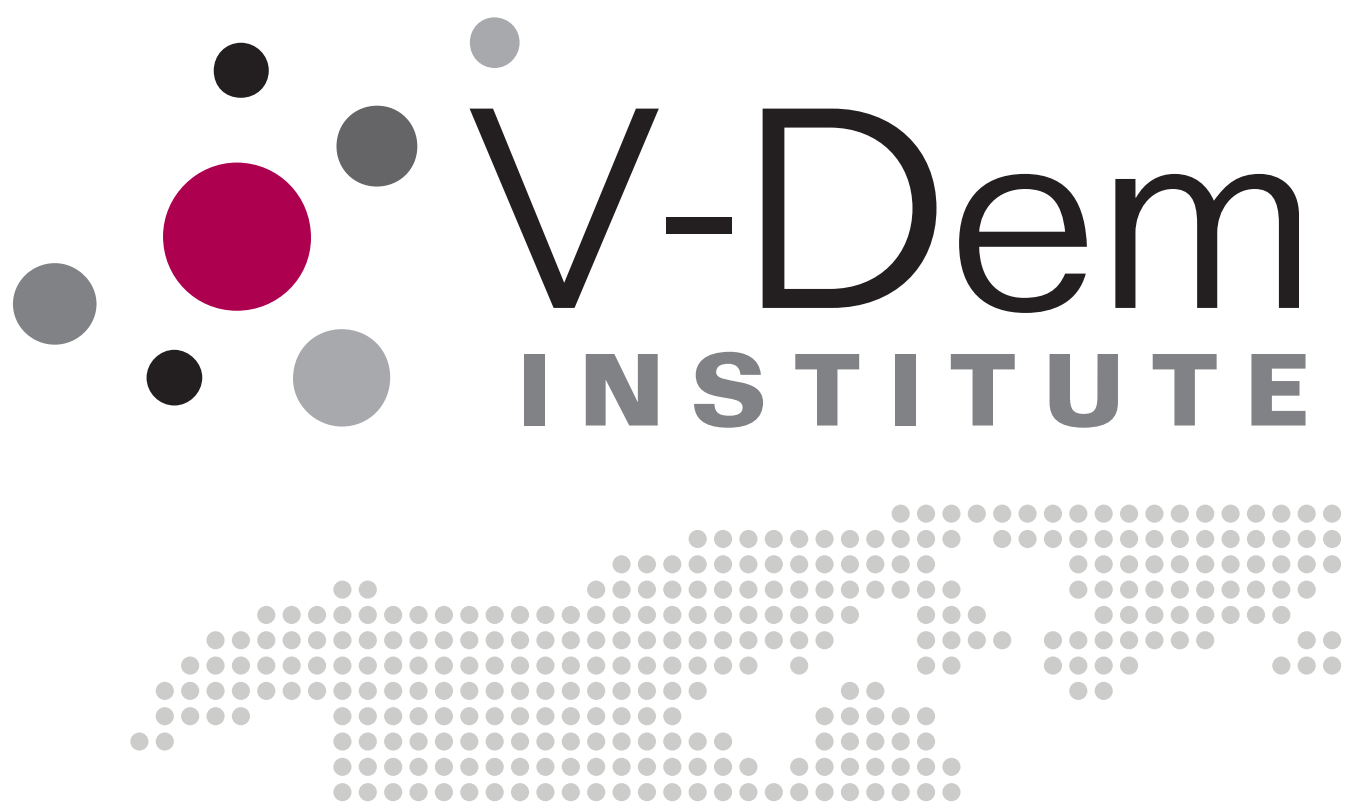

Explaining the Homogeneous Diffusion of Covid-19 Policies among Heterogenous Countries

Abiel Sebhatu, Karl Wennberg, Stefan Arora-Jonsson, Staffan I. Lindberg

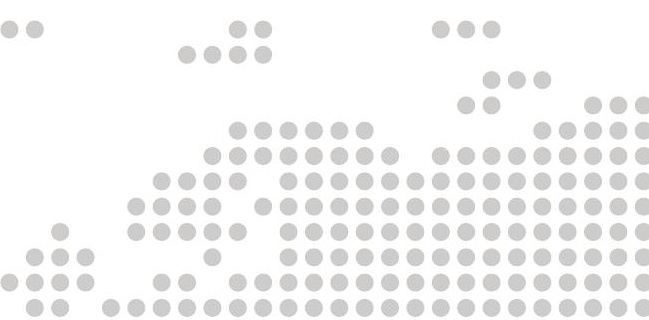
100000000000000000

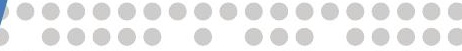

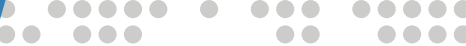
00000000000008

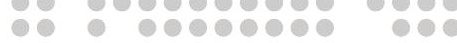

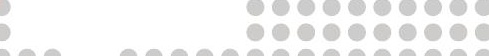

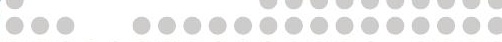
1000000000000000000 бе00000800000000

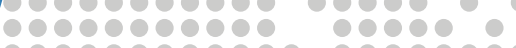

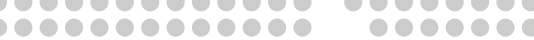

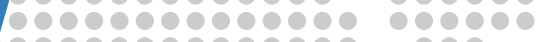
100000000000000 3000000000000000 20000000000000000000 100000000000000000000

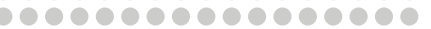

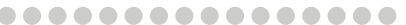
८०००००00000000 000000000000 0000000000 00000000000

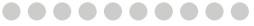
-

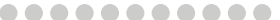
00000000000

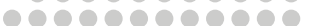
-

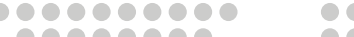

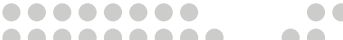
000000000 0000000

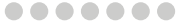
00000 00000000 000000 000000 00000 100000 1009 000 0 00 80 000 100 0 
Varieties of Democracy (V-Dem) is a new approach to conceptualization and measurement of democracy. The headquarters - the V-Dem Institute - is based at the University of Gothenburg with 19 staff. The project includes a worldwide team with six Principal Investigators, 14 Project Managers, 30 Regional Managers, 170 Country Coordinators, Research Assistants, and 3,000 Country Experts. The V-Dem project is one of the largest ever social science research-oriented data collection programs.

Please address comments and/or queries for information to:

V-Dem Institute

Department of Political Science

University of Gothenburg

Sprängkullsgatan 19, PO Box 711

SE 40530 Gothenburg

Sweden

E-mail: contact@v-dem.net

V-Dem Working Papers are available in electronic format at www.v-dem.net.

Copyright (C2020 by authors. All rights reserved. 


\title{
Explaining the Homogeneous Diffusion of Covid-19 Policies among Heterogenous Countries*
}

\author{
Abbreviated version published Aug. $11^{\text {th }}$ in the Proceedings of the \\ National Academy of Sciences (PNAS): \\ https://doi.org/10.1073/pnas.2010625117
}

\begin{abstract}
Abiel Sebhatu ${ }^{1}$
Institute for Analytical Sociology (IAS), Linköping University, SE-601 74 Norrköping, Sweden

abiel.sebhatu@liu.se

Karl Wennberg

Institute for Analytical Sociology (IAS), Linköping University, SE-601 74 Norrköping, Sweden

karl.wennberg@liu.se

Stefan Arora-Jonsson

Department of Business Studies, Uppsala University, Sweden \& Department of Management, Universita della Svizzera, Italiana, Lugano, Switzerland stefan.jonsson@fek.uu.se

Staffan I. Lindberg

V-Dem Institute. Department of Political Science. University of Gothenburg, Sweden xlista@gu.se
\end{abstract}

\footnotetext{
* We are grateful for comments from E-seminar participants at the Ratio institute, Aalto University, Stanford University, Stockholm School of Economics, Rotterdam School of Management, EMLYON, Institute for Analytical Sociology (IAS) at Linköping University, Gustav Almqvist, Tom Christensen, Grégoire Croidieu, Anna Dreber Almenberg, Robert Eberhardt, Gustaf Edgren, Julia Fleischer, Jacob Habinek, Kim Klyver, Woody Powell, Chiqui Ramirez, Chris Rider, and Jingcheng Zhao. All errors remain those of the authors. Wennberg acknowledges funding from the Royal Swedish Academy of Letters. Lindberg acknowledges funding from European Research Council, Consolidator Grant 724191, Knut and Alice Wallenberg Foundation to Wallenberg Academy Fellow Staffan I. Lindberg, Grant 2018.0144, as well as co-funding from the University of Gothenburg. Importantly, our article does not address the effectiveness of any particular public policy in curtailing the spread of the Covid-19 virus.

${ }^{1}$ Corresponding author
} 


\begin{abstract}
The need for non-pharmaceutical interventions aimed at curtailing the spread of infectious diseases depends crucially on country-specific demographic and public health situations. However, the early stages of the Covid-19 pandemic saw an almost homogeneously rapid adoption of such interventions across otherwise heterogeneous countries. We analyze the adoption of disease-transmission interventions in the OECD countries, and find that they are only weakly predicted by standard epidemiological indicators (confirmed infections, deaths, intensive care capacity) but strongly predicted by standard indicators in the literature on diffusion of interventions (number countries adopting the same policy; in particular, the number of proximate countries). We also examine whether the level of democracy in a given country influences the speed at which it adopts such interventions. We provide insights for research on international policy diffusion and the emerging strand of research pondering the political consequences of the Covid-19 pandemic.
\end{abstract}

Keyword: Covid-19 Pandemic, Policy diffusion 
Following the Covid-19 outbreak, various policy measures—often known as "nonpharmaceutical interventions" (NPIs) - have been implemented by countries worldwide in order to restrict individual movement and behavior. These policies include school closures, travel restrictions, curfews, and quarantines. Such interventions are motivated by the need for 'social distancing' in order to 'flatten the curve'-i.e. slow the spread of the Covid-19 virus (SARS-CoV-2) ${ }^{2}$ so that the healthcare system can adapt and is not overwhelmed.

The timing of NPIs is crucial, but determining the optimal timing is fiendishly difficult. Waiting too long may lead to the spread spiraling out of control and overwhelming the healthcare system, with tragic effects—as seen in northern Italy. On the other hand, introducing interventions too early or too uniformly across entire countries may also be perilous, since it may increase the risk of a 'second wave' of infections once initial interventions are halted (Davies et al., 2020; Ferguson et al., 2020). Every intervention also carries a social and economic cost in terms of increased isolation and lost economic activity. Interventions are also dependent on citizens' willingness to comply with them-a willingness that is likely to wane over the course of the intervention (Briscese et al., 2020).

Given these complexities we might expect individual countries to carefully evaluate the timing of their NPIs, and tailor the exact schedule to their own specific needs. It is therefore surprising to see how homogeneous countries have been in the timing of the adoption of interventions (Ferguson et al., 2020). Figure 1 shows that four out of five Covid19 NPIs spread to about 80 percent of the OECD countries within a period of two weeks in March. ${ }^{3}$ Given the heterogeneity among these countries in terms of the preparedness of their healthcare systems, their population demography, and the degree to which the pandemic had taken hold in each country at this time, the homogeneity in timing of adoption is striking.

\footnotetext{
2 To simplify the terminology, we refer to policies or interventions seeking to slow the spread of the SARSCoV-2 virus as "Covid-19 NPIs."

3 Our analysis includes the five most common "interventions" or "policies," as they are also referred to (school and workplace closures, cancellation of public events, closure of public transportation, and citizen mobility restrictions) as coded by the Oxford COVD-19 Government Response Tracker (Hale et al., 2020). We also show and model the more widely used policy of "public information campaigns," which is not an NPI per se.
} 
Figure 1. Adoption of Covid-19 policies, OECD countries

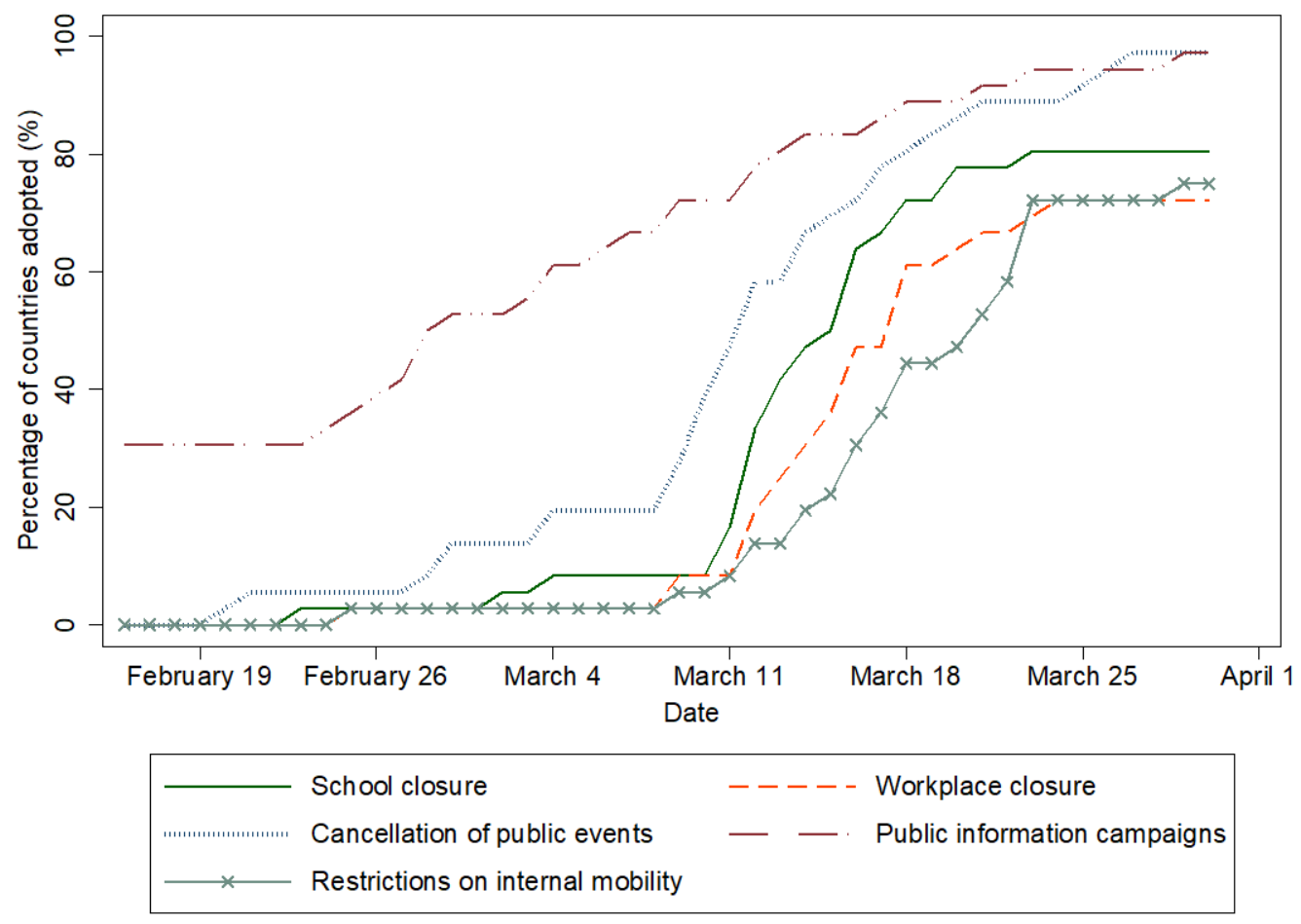

While researchers across scientific disciplines struggle to gauge the efficacy of these Covid19 policies, a key task for social scientists is to explain why public decision-makers responded as they did during the early outbreak of the pandemic. In this paper, we address the question of the timing of policies adopted to flatten the curve among the OECD countries. The OECD comprises advanced economies with fairly well-developed healthcare systems, in which decision-makers are exposed to political opposition and (mostly) democratic institutions. Consequently, OECD countries all face high uncertainty in the trade-offs of enacting far-reaching policies to counter the spread of the Covid-19 virus.

Our core contention is that in order to understand the timing of NPIs, we must look beyond the standard technocratic and rationalistic explanations of adoption (J. G. March, 1994). A long tradition in research on public decision-making shows that less rational factors can also play an important role, especially under conditions of uncertainty (J. G. March, 1994; J. G. March \& Olsen, 1975) — as is the case with NPIs. A standard prediction is that when the effect of a decision is uncertain, decision-makers often do what others do, and implementation is thus guided by a mix of mimicry and necessity. One driving motivation 
for such behavior is the criticism incurred by looking like "the laggard"-i.e. the country that is far too slow to act (Shipan \& Volden, 2012). Such pressures can come from both within the country itself, and from its neighbors. Moreover, the context in which decision-makers make such choices can differ significantly across countries, as their democratic systems and decision rights, varies. All else being equal, a system that requires more deliberation is likely to be slower to react. A democratic system could thus, to some extent, counter a propensity to speed up adoption because of the adoptions by other countries.

Our paper investigates to what extent the timing of implementing Covid-19 policies among OECD countries can be explained by mimicry and differences in democratic systems between countries, over and above epidemiological and demographic factors predicting the necessity of policy adoption. Such an analysis of is vital for at least three reasons:

First, contemporary scholarly debate surrounding NPIs has largely focused on their relative efficacy, either separately (Ioannidis, 2020; Jefferson et al., 2011) or when enacted simultaneously (Anderson et al., 2020; Ferguson et al., 2020). Such discussions presume that the timing of the policy adoption is uninteresting — whereas timing is actually crucial for the efficiency and efficacy of an intervention, as well its economic and social costs. Paying due attention to the timing of interventions helps advance the debate from a binary 'whether or not' discussion to a more nuanced consideration of 'whether and when'. Moreover, focusing on adoption timing recognizes the issue of the sustainability of the interventions-a question that is gaining importance amid increasing evidence of 'lockdown fatigue' (Karlson, Stern, \& Klein, 2020).

Second, because we know little with certainty about the effects of specific NPIs, public health authorities and governments have been forced into snap decisions over whether to enact or abstain from policy options with uncertain trade-offs. Models for decision-making under such conditions are widespread in the political and behavioral sciences (e.g. March \& Olsen, 2013; Tetlock, 1996), but to date have not been used to explain policy choices during the Covid-19 pandemic (but see Qi et al., 2020, for a decision making perspective on Chinese health officials' initial policy recommendations). By examining the timing of Covid19 NPIs, our paper sheds light on the underlying causal mechanism surrounding policy adoption of public health interventions following a major pandemic outbreak, and provides a useful starting point for evaluating countries' ability to follow the WHO Director-General's recommendation to "innovate and learn" as they seek to handle the pandemic (WHO, 2020). 
To the extent that such "learning" is primarily driven by mimicry rather than adaptation to necessity, a behavioral science perspective on policy responses to the pandemic is useful (Shipan \& Volden, 2012; Van Bavel et al., 2020).

Third, our analysis of how pandemics may spur the rapid adoption of interventions that curtail citizens' civil liberties, work, and day-to-day lives contributes to research on the political consequences of exogenous events such as pandemics. As of early May 2020, over 100 countries had enacted various forms of emergency legislation further concentrating power in the executive, and a recent estimate suggests that 82 countries are at high or medium risk of "pandemic backsliding" on democracy (Wilson et al., 2020).

\section{International policy diffusion under uncertainty}

The question of whether interventions are adopted according to need or mimicry has been well studied in the fields of political science and sociology. It is normally considered in terms of the diffusion of interventions between states/regions and between countries (Brinks \& Coppedge, 2006; Shipan \& Volden, 2008; Simmons \& Elkins, 2004), or as “emulation,” which denotes an active uptake on the part of the receiving country (Brinks \& Coppedge, 2006). "Diffusion" is a general term for the process by which something-for instance, a new policy—spreads throughout a group, such as nation states (Rogers, 1995). Here, the diffusion of a policy among sovereign countries is seen as a function of its perceived usefulness, and usefulness is broadly determined by the policy's "fit" with the needs of the nation. Because countries may learn about a new policy at different times, and because countries are heterogeneous in terms of their need for a particular policy, new interventions typically do not spread to all countries at the same time. As a result, most interventions spread gradually_from "early adopters" to "laggards" — and not all interventions are ultimately adopted by all countries. A key question for diffusion studies concerns what distinguishes an "early" adopter from a "late" one, and what the maximum diffusion of the policy might be (Katz, Levin, \& Hamilton, 1963).

The diffusion process is typically theorized as being dependent on two main factors: the spread of information by which countries come to learn about the policy, and the perceived need for the policy (Rogers, 1995). Countries learn not only about the existence of a new policy, but also about its usefulness for earlier adopters-and this learning is reflected in the perceived need for the policy (Levitt \& March, 1988). The spread of information 
about a policy is related to the number of earlier adopters; as the number of adopters increases, so information about the policy becomes more widely spread. Central to our discussion, the number of earlier adopters can also serve as a form of "validation" of the usefulness of a policy, as well as an indication of its positive normative value (Ahmadjian \& Robinson, 2001; Strang \& Soule, 1998; Tolbert \& Zucker, 1983). Furthermore, if the policy becomes imbued with a positive normative value - i.e. it is "good" to have adopted it — the number of earlier adopters can enhance the perceived usefulness of adoption in order to avoid being considered a "laggard," leading to a race to adopt (Wejnert, 2002). Collective behaviors also allow decision-makers to claim credit for positive outcomes while avoiding blame for negative ones (El Zein, Bahrami, \& Hertwig, 2019). Diffusion processes are thus shaped by the fit of a policy with the needs of potential adopters, and also by the pressure to adopt that is imposed by earlier cumulative adoption among other countries.

The importance of earlier adoptions depends critically on the uncertainty of the efficacy of adoption of the policy in question: the more uncertainty surrounding the policy, the greater the influence of earlier adoptions (Greve, 1995; Haunschild \& Miner, 1997; J. G. March, 1994). When the effects of a policy are uncertain, decision-makers are more likely to look to the experiences of others to gauge the appropriateness of adopting the policy in question (Levitt \& March, 1988). However, rather than emulating the decisions made in "any other country," decision-makers focus on those countries that are considered more relevant as a comparison or benchmark. Most generally, geographic clustering based on shared borders or spatial proximity has been shown to make countries more likely to look to each other for cues (Brinks \& Coppedge, 2006; Gleditsch \& Ward, 2006; Leeson \& Dean, 2009; O'loughlin et al., 1998). Countries may also be more strongly influenced by countries with whom they share a religion, and therefore norm systems (Mainwaring \& Pérez-Liñán, 2013, pp. 93-123; Woodberry, 2012), or those with whom they have a high intensity of relations, and thereby interdependence (Levitsky \& Way, 2006).

The choices facing public decision-makers during an unknown and rapidly spreading pandemic poses an ideal test bed for such arguments, since the efficacy of various interventions is highly uncertain and widely debated. Adoption timing is a central issue. Most Covid-19 NPIs carry a heavy and direct economic cost for the adopter, which means that every "extra" day that a restriction remains in place imposes an additional economic burden 
on society. Closing schools means that parents need to stay at home, closing workplaces puts jobs and firms at risk, and closing borders limits the economic exchange among countries.

One of the most widely shared academic studies — cited by political decision-makers such as U.S. President Donald Trump—is Imperial College's simulation study assessing "the impact of non-pharmaceutical interventions (NPIs) to reduce COVID19 mortality and healthcare demand” (Ferguson et al., 2020, released March 16th). This report explicitly notes "many uncertainties in policy effectiveness" and "very large uncertainties around the transmission of this virus, the likely effectiveness of different interventions and the extent to which the population spontaneously adopts risk reducing behaviors." Based on simulation results for five Covid-19 NPIs (case isolation in the home, voluntary home quarantine, social distancing for over-70s, social distancing for the entire population, and closure of schools and universities) the report suggests that a minimum policy for effective suppression is "population-wide social distancing combined with home isolation of cases and school and university closure." The report also suggests that interventions such as a ban on public events and other mass gatherings have relatively little impact.

In addition to these uncertainties, there is also the question of the sustainability of efforts. While it has always been evident that interventions are only as effective as the willingness of the population to abide by them, it has also become clear that such willingness can wear off, in what has been called "lockdown fatigue" (Briscese et al., 2020; Karlson et al., 2020). If a society has a maximum number of days during which it will be fully compliant with an intervention, it is important to time the implementation in order to make that intervention as sustainable as possible.

As Figure 1 shows, countrywide school closures and bans on public events are among the most prevalent Covid-19 NPIs recently adopted by OECD countries. A striking feature of this graph is the apparent homogeneity in the decision to adopt four out of five restrictions; within a span of two weeks, almost 80 percent of the OECD countries adopted the same four restrictions. This is interesting against the background of these countries being heterogeneous, and the fact that the relative efficacy of these and other interventions is still clouded by uncertainty. In a recent overview examining these uncertainties and the limited evidence base for Covid-19 NPIs, Ioannidis (2020) advances the explanation that "[p]olicymakers feel pressure from opponents who lambast inaction. Also, adoption of measures in one institution, jurisdiction or country creates pressure for taking similar 
measures elsewhere under fear of being accused of negligence" — and, as a consequence, that "priorities can become irrational." A set of models designed to incorporate the effect of potentially irrational decision-making can be found in the literature on policy diffusion explaining countries' actions under uncertainty, which we outline below.

\section{Proposition one: Policy adoption by mimicry}

If countries look beyond their own situation and also mimic each other in the decision to adopt NPIs, then we expect that the number of prior adoptions of a practice would matter to the adoption decision of a focal country-over and above the influence of epidemiological variables such as epidemic incidences, the capacity of the healthcare system, and the demography of the population. However, even if we were to estimate a significant positive effect of the total number of earlier adoptions, the interpretation of such a finding is unclear. While it could be that countries are emulating each other, it could also just reflect the fact that countries are all facing a similar problem and therefore take alike actions more or less simultaneously. To strengthen the inferential power of including earlier adoptions in a diffusion analysis, it is common practice to use theory to derive a measure for mimicry that is more specific than all earlier adoptions. As discussed above, a standard finding in diffusion studies is that proximity — social, cultural, geographical—predicts facsimile behavior (Strang \& Soule, 1998). In our case, there is no clear reason why social or cultural proximity would influence the adoption of Covid-19 NPIs, so we adopt the most generic form of similarity: geographical proximity. The logic is that information about efficacy, the likelihood of seeing the adoption experiences of another country as relevant, and the risk of unfavorable comparisons with respect to the pace of policymaking is greater for countries that are geographically closer than for those that are further apart. This does not mean that the

adoption of countries that are further away does not matter at all, but rather that we expect it to matter relatively less.

Hypothesis 1. The more neighboring countries adopt a Covid-19 policy, the faster a focal country will adopt the same policy-all else being equal.

\section{Proposition two: How variety of democracy across countries affects policy actions under uncertainty}


Political decision-making theory holds that it is not only what others have done that may influence the decision to adopt, but also the context of the decision-maker, as this sets expectations on how decisions should be made (J. G. March, 1994; J. G. March \& Olsen, 1976). In our context, the relevant decision-makers are elected political leaders. However, democracy is not a unitary concept, but should be seen as a spectrum of different types of decision-making contexts (Teorell et al., 2019). Even so, the empirical research problem at hand demands that we make a pragmatic choice, and we follow R. Dahl (1971) in defining democracy as the extent to which rulers and their interventions are responsive to citizens through the institutions of power vested in officials elected in clean elections with extensive suffrage, and an enabling environment of freedom of expression and association. In highly democratic countries, virtually all adults have the right to vote and elections are free from manipulation and distortions such as unfair media coverage, undue influence of capital, votebuying, or other irregularities. Freedom of speech is also guaranteed, and both media and civil society are independent, responsible, and contribute both to holding the government accountable and to educating the public.

It is not clear ex ante whether one should expect highly democratic countries to adopt policies more quickly than their less democratic counterparts (Bader, Grävingholt, \& Kästner, 2010; Gleditsch \& Ward, 2006; Houle \& Kayser, 2019). When it comes to adopting radical interventions to contain the spread of Covid-19, democracies might be expected to be slower than dictatorships, or the other way around, for different reasons. One might, for example, expect democratic countries to act more quickly in adopting strict interventions to counter an imminent pandemic, because democratically elected leaders depend on public approval to stay in power. This should give them strong incentives to signal decisiveness in times of crisis, and to place a high priority on citizens' public health (Besley \& Kudamatsu, 2006). Further, free media and freedom of expression should improve both the quantity and quality of information available for rapid disaster responses (Persson \& Povitkina, 2017), although this may also serve as a conduit of fake news and conspiracy theories.

However, it is also plausible that drastic policy interventions are more difficult to enact in countries with more developed electoral democracy. Democracies have wideranging rights and freedoms that autocracies and less developed democracies lack (e.g. Diamond, 2002). Policymakers' reluctance to encroach on liberties inherent in democracies may lead them to hesitate when contemplating interventions that limit these freedoms 
(Robert Alan Dahl, 1989). Second, leaders in democracies face a great uncertainty regarding citizens' reactions to far-reaching interventions entailing restrictions on their personal freedom, even if those interventions are motivated by public health concerns. Negative public perceptions jeopardize politicians' hold on power in democracies, but far less so in autocracies (Sartori, 1987). A strong civil society and free media put politicians at risk of fierce resistance and mass mobilization against interventions the public may not approve of (Foreign Policy, 2020). Third, strong democracies tend to have relatively robust mechanisms of horizontal accountability, where opposition parties in the legislature, law courts, and other independent state bodies all have a say in shaping policy (O'Donnell, 1998). As a consequence, democratic decision-making is more of a deliberative process regulated by institutions to prevent governments' abuse of power, meaning it also takes more time to turn ideas into legislation (Przeworski et al., 1999). During this process, democracies' transparency typically leads to debates in the media involving civil society actors, where alternatives are weighed and considered (Rose-Ackerman, 1996). It is not uncommon that the original propositions must be reworked before being discussed again. This further adds to our expectation that countries with a high level of democracy would be slower in deciding on restrictions on civil liberties in response to a pandemic such as Covid-19.

\section{Hypothesis 2. The more democratically developed a country, the slower it will adopt Covid-19 policies-all else being equal.}

Our baseline counterfactual is that the speed at which countries adopt interventions to curtail the Covid-19 pandemic is a function of standard epidemiological and demographic indicators suggesting those countries are "at risk" of a serious outbreak. The two key indicators we use are the number of reported infections and number of deaths in the population ascribed to the Covid-19 virus, normalized by population size. ${ }^{4}$ Moreover, indicators of a country's capabilities for handling an outbreak, as well as its population density and age demography, are important. A country that has experienced many deaths and has a weak healthcare system along with a dense and ageing population should thus be early to adopt.

\footnotetext{
${ }^{4}$ In unreported models (available upon request) we used the number of reported infections and number of deaths without normalizing for population size, with close to identical results.
} 


\section{Methods and data}

Our data comes from the Oxford Covid-19 Government Response Tracker (OxCGRT) (Hale et al., 2020), the Varieties of Democracy (V-Dem) database (Coppedge et al., 2020), the World Bank ${ }^{5}$, and the OECD ${ }^{6}$. The variables measuring countries' Covid-19 NPIs are drawn from OxCGRT, which also includes daily counts of the number of people infected and number of deaths related to the Covid-19 virus for each country in the OECD between January 15 and March 30, 2020. We focus on the OECD since it represents a group of countries that are relatively homogeneous from an economic and democratic perspective, which means that the alternative cost of policy adoption will be similar across these countries and they have similarly developed democratic systems. Furthermore, these countries have similarly well-developed healthcare systems. The OECD countries all face high uncertainty over the trade-offs involved in enacting far-reaching NPIs or not, and decision-makers are exposed to political opposition that may take advantage of them making unnecessary or excessive interventions, or, conversely, failing to enact a policy that has proven successful elsewhere. If non-epidemiological factors can explain the spread of Covid19 NPIs across countries, it should be relatively harder to detect such patterns in a group of well-developed economies like the OECD countries.

Table 1. Covid-19 policy variables (OxCGRT)

\begin{tabular}{|c|c|c|c|c|}
\hline ID & Name & Description & Description & Coding instructions \\
\hline S1 & School closure & $\begin{array}{l}\text { Record closures of } \\
\text { schools and } \\
\text { universities }\end{array}$ & \multirow{4}{*}{$\begin{array}{l}\text { Ordinal scale }+ \\
\text { binary for } \\
\text { geographic scope }\end{array}$} & \multirow{4}{*}{$\begin{array}{l}0: \text { No measures } \\
\text { 1: Recommend closure } \\
\text { 2: Require closure } \\
\text { 0: Targeted } \\
\text { 1: General }\end{array}$} \\
\hline S2 & Workplace closure & $\begin{array}{l}\text { Record closures of } \\
\text { workplaces }\end{array}$ & & \\
\hline S3 & $\begin{array}{l}\text { Cancellation of public } \\
\text { events }\end{array}$ & $\begin{array}{l}\text { Record canceling } \\
\text { public events }\end{array}$ & & \\
\hline S4 & $\begin{array}{l}\text { Closure of public } \\
\text { transportation }\end{array}$ & $\begin{array}{l}\text { Record closure of } \\
\text { public transport }\end{array}$ & & \\
\hline S5 & $\begin{array}{l}\text { Public information } \\
\text { campaigns }\end{array}$ & $\begin{array}{l}\text { Record presence of } \\
\text { public information } \\
\text { campaigns }\end{array}$ & $\begin{array}{l}\text { Binary }+ \text { binary on } \\
\text { geographic scope }\end{array}$ & $\begin{array}{l}\text { 0: No Covid-19 public } \\
\text { information campaign } \\
\text { 1: Covid-19 public information } \\
\text { campaign } \\
\text { 0: Targeted } \\
\text { 1: General }\end{array}$ \\
\hline
\end{tabular}

${ }^{5}$ https:// data.worldbank.org/

${ }^{6}$ https://data.oecd.org/ 


\begin{tabular}{|l|l|l|l|l|}
\hline S6 & $\begin{array}{l}\text { Restrictions on } \\
\text { internal mobility }\end{array}$ & $\begin{array}{l}\text { Record restrictions } \\
\text { on internal } \\
\text { movement }\end{array}$ & $\begin{array}{l}\text { Ordinal scale }+ \\
\text { binary for } \\
\text { geographic scope }\end{array}$ & $\begin{array}{l}\text { 0: No measures } \\
\text { 1: Recommend movement } \\
\text { restriction } \\
\text { 2: Restrict movement }\end{array}$ \\
& & & $\begin{array}{l}\text { 0: Targeted } \\
\text { 1: General }\end{array}$ \\
\hline
\end{tabular}

Table 1 summarizes the variables included in our study. Intervention/Policy adoption is coded on an ordinal scale ranging from $0-3$, and there is also an indicator of whether the policy is "targeted"-i.e., that it only applies within a specific geographical area-or "general"-i.e., that it applies nationwide. The ordinal coding allows for the construction of a "stringency index," which scores the stringency of policy adoption as an index of the number of policy measures adopted, whether it is a recommendation or requirement, and whether it is targeted or general.

\section{Dependent variable}

We focus on the speed of adoption of the different Covid-19 policies described in Table 1 (for a similar model see Adolph et al., 2020 analysis of US States). We do not include the policy "Closure of public transportation" in our statistical analysis since there were only 9 countries adopting this policy throughout the country. ${ }^{7}$ For these analyses we construct a $0 / 1$ adoption variable for each policy by coding the variable " 1 " the day a general policy is adopted (i.e., becomes applicable to the whole country) and " 0 " otherwise. ${ }^{8}$

Figure 1 shows the accumulated adoptions of Covid-19 NPIs from January 15 2020, when the first confirmed case was reported in the OECD countries. The first policy adopted extensively was public information, followed by cancelations of public events and gatherings and school closures. Closure of workplaces and restriction on internal mobility tends to be implemented a little later, while closure of public transport is implemented relatively late, and by few countries. This is reasonable, given the greater direct economic costs to society of closing workplaces and public transport networks.

\footnotetext{
${ }^{7}$ Including Closure of public transportation in the main analysis (Table 2) did not alter the main results (available on request). Due to the low number of adoptions it could not be included in the post-hoc analyzing separate policies (Appendix B).

${ }^{8}$ Robustness tests distinguishing between whether the general policy adopted is " 1 " recommended or " 2 " required produced no substantial difference in results (see page 17).
} 


\section{Predictor variables}

Our hypotheses propose that countries' adoptions of Covid-19 NPIs are affected by, over and above standard epidemiological predictor variables, (1) prior countries' adoption of similar measures and (2) the level of democracy in a focal country. These hypotheses are tested using two main predictor variables:

Adoption density (OECD region) is a cumulative measure of prior adoptions of a particular policy among countries in spatial proximity to a focal country (Brinks \& Coppedge, 2006; Gleditsch \& Ward, 2006; Leeson \& Dean, 2009; O'loughlin et al., 1998). ${ }^{9}$ It is measured as the cumulative number of policy adoptions within a region based on the United Nations' (UN) classification and definition of regions: Western Europe, Eastern Europe, Southern Europe, Northern Europe, Asia \& Pacific, and Americas. To avoid small cell sizes, we grouped "Asia" to include both western and southern Asia, and "Americas" to include North and South America as well as Latin America. ${ }^{10}$ This variable thus probes whether policy adoption is relatively more strongly driven by the cumulative number of policy adoptions in nearby countries (Adolph et al., 2020). ${ }^{11}$ Our main analysis includes all types of policies adopted by other countries in the OECD region (Table 1). In the supplementary analysis, modeling all the policy types separately, adoption density (OECD region) measures only that specific type of policy adopted by other countries in the OECD region.

Electoral democracy. The most important decision-making context for the adoption of interventions is the democratic system of the nation. We use the 2019 Electoral Democracy Index (EDI, v2x_polyarchy) from the Varieties of Democracy (V-Dem) database (Coppedge et al., 2020). EDI is derived from expert surveys of $3000+$ country experts from around the world, with a minimum of five experts rating each of the 43 indicators measuring institutions of democracy: 1) Elected Officials, 2) Clean Elections, 3) Associational Autonomy, 4) Inclusive Citizenship, and 5) Freedom of Expression and Alternative Sources of Information

\footnotetext{
${ }^{9}$ Much of the recent diffusion modeling has sought to trace networks of influence, i.e. playing different possible pathways off against each other in an analysis in order to identify the "true" or most influential path (Strang \& Soule, 1998). Our hypotheses and analyses are not concerned with the particular path of influence, but rather with the extent to which countries' adoptions of Covid-19 NPIs are influenced by other countries. We thus use the OECD classification of countries, which captures possible pathways of influence.

10 https://unstats.un.org/unsd/methodology/m49/

${ }^{11}$ In unreported models (available upon request) we also examined adoption density (OECD), which measures accumulated prior adoptions of a policy among all the OECD countries. Results were similar but of weaker magnitude, and since the two variables are collinear, we report results for Adoption density (OECD region) only.
} 
(R. Dahl, 1971; Robert A Dahl, 2008). The EDI ranges from 0 to 100 where 0 indicates pure dictatorship and 100 that electoral democracy is achieved in its fullest sense. ${ }^{12}$

Figure 2. Speed of Covid-19 policy adoption and level of electoral democracy
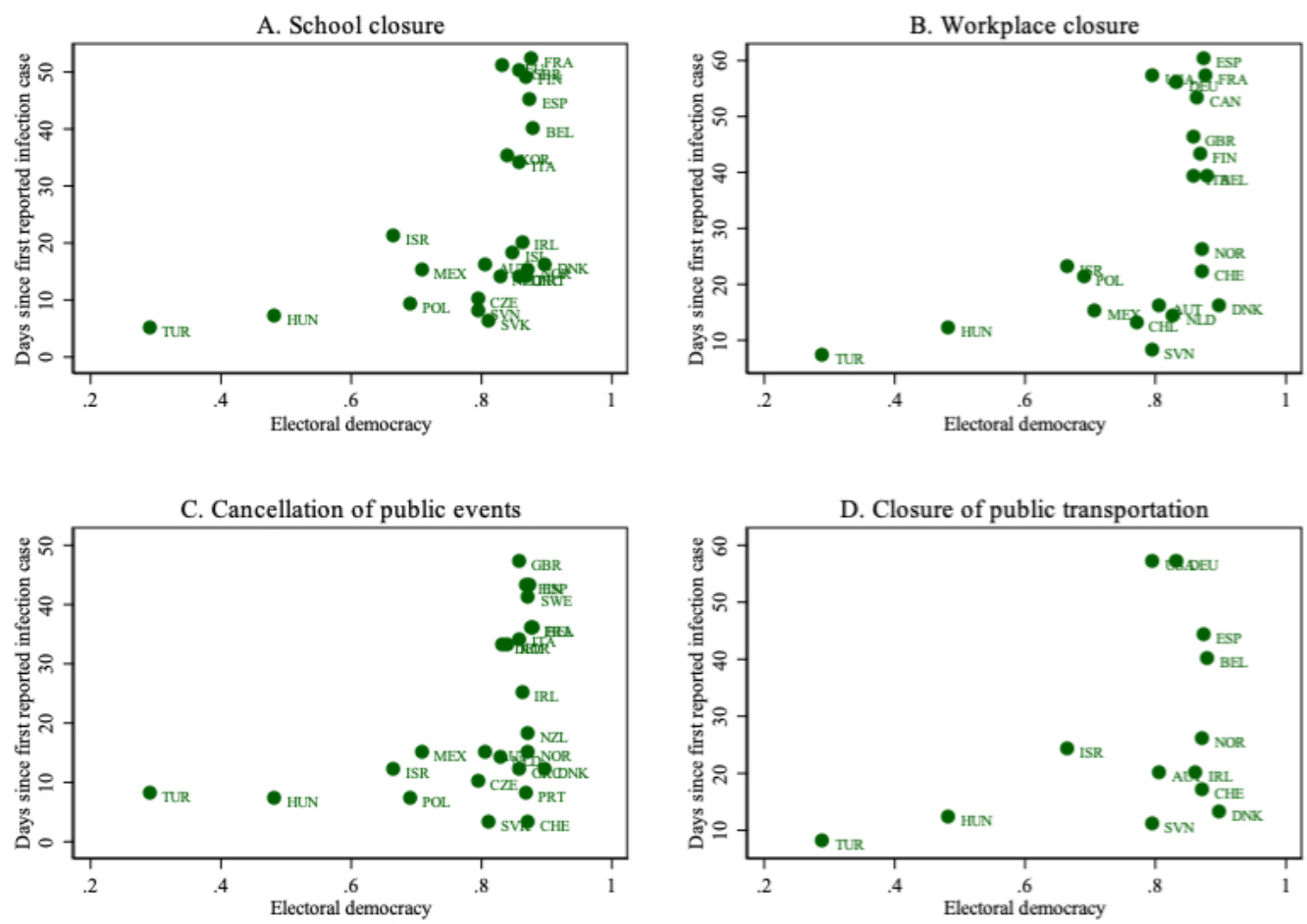

Figure 2 shows the correlation between electoral democracy and the time that elapsed before OECD countries adopted various Covid-19 NPIs. It indicates that countries with a low democracy score were relatively quicker to adopt Covid-19 NPIs, but also that there is a sizeable variation among countries with high levels of democracy. ${ }^{13}$ The electoral democracy index has a high mean (83) and low standard deviation (9), which is expected given that we study OECD countries that all score quite high on the democracy index (see Appendix A).

\section{Control variables}

Since the main objective of countries' Covid-19 interventions is to counteract the spread of the Coronavirus, it is essential to control for (1) the number of confirmed cases of people

$12 \mathrm{~V}$-Dem's original index has a range $[0,1]$, which we rescaled for the sake of consistency and ease of interpretation. See also V-Dem's methodology (Coppedge et al. 2020).

13 To account for potential outliers of electoral democracy, e.g. Turkey and Hungary in the lower tail, or Spain and France in the upper tail, we winsorized the variable for both $5 \%$ and $10 \%$ in each tail of the distribution. All results remained robust and were actually more pronounced when accounting for these outliers. 
infected by Covid-19 in the focal country, and (2) the number of deaths due to the virus. We scale these variables by dividing them by the country's population size $\left(/ 100^{\prime}\right) .{ }^{14}$ The measures of confirmed cases and deaths account for what is publicly reported by each country, and in many ways may underpin the process policy-adoption diffusion hypothesized above. Both variables come with known measurement errors and are thus not equivalent to validated SEIR (Susceptible, Exposed, Infectious, and Removed) measures used to estimate a disease's reproduction number in epidemiological infectious disease models (see e.g. Wang et al., 2020). It is likely that cases and deaths are underreported (New York Times points to up to $50 \%$ underreporting of Covid-19 deaths in countries such as Turkey, and 20-30\% underreporting in many European countries, as compared to expectations based on average fatalities data) (NYT, 2020). While the true figures may not be known until some time in the future, our study is in line with studies interested in the timing of policy adoptions during the pandemic itself (Adolph et al., 2020), ${ }^{15}$ rather than their impact on infection and death rates (Flaxman, Mishra, \& Gandy, 2020; Wang et al., 2020). Importantly, we can expect that decision-makers are sensitive to official figures.

We also include a range of time-invariant variables in order to control for a country's economic, demographic, and public-health related characteristics. These variables are obtained from the World Bank. ${ }^{16}$ The economic variables include the natural logarithm of gross domestic product (GDP) per capita, tax revenues (\% of GDP), and income inequality (GINI index). We control for differences in demography and care capability with the variables number of hospital beds (/1,000 people), the percentage of population aged 65 or older, and the percentage of the population living in urban areas. ${ }^{17}$ Older people are of importance since they are

\footnotetext{
${ }_{14}$ These two variables are highly collinear, and we therefore report only death rate (the variable having maximum influence in our model) in the main results reported. Replacing death rate with confirmed cases (Appendix D) did not change any of the main results reported. Confirmed cases has similar but arguably even larger measurement errors than death rate, since it depends crucially on the testing carried out in each country.

15 While confirmed cases of Covid-19 are undercounts of actual cases, confirmed cases are the only data available to officials making decisions in real time. We explored a variety of alternative measures, including whether the state had 10 or more confirmed cases, but found substantively similar results. All results were also robust to the inclusion of standard controls for systematic variation in public statistics provided across countries (Cepaluni et al., 2020; Williams, 2015), indicating that such variation is low across the OECD countries. All of these tests are available upon request.

${ }^{16}$ GDP and population variables are from 2018, GINI from 2017 except for South Korea (2012), New Zealand (2014), Australia (2014), and Turkey (2018). Hospital beds are from 2013 for three-quarters of all countries, and from 2014-2015 for the rest. In a separate model we fit fixed effects model that excluded all time-invariant variables (including the electoral democracy index) and the results did not change.

17 "Urban population" refers to people living in urban areas as defined by national statistical offices. The data are collected and smoothed by United Nations Population Division of the World Bank (2019).
} 
regarded as being more vulnerable to Covid-19 (Gavazzi \& Krause, 2002). We also include population density (per square kilometer), since the virus may be less likely spread in sparsely populated countries (Hauck, 2018). ${ }^{18}$

\section{Event history models of timing of Covid-19 policies}

We use event history models to test our hypotheses related to the timing of implementing Covid-19 NPIs in the OECD countries between January 15 and March 30, 2020. Our model examines what factors predict the adoption of any, some, or all of the general policy interventions describes in Table 1, excluding "Closure of public transportation" (see footnote 7). Since these interventions can be enacted at any time or in any order (or not at all), the data is organized as a multiple failure-time dataset and estimated as a semiparametric cox proportional event history model, also called the marginal risk set model (Wei, Lin, \& Weissfeld, 1989) with the functional form:

$$
h_{i j}(t)=h_{0}(t) * \exp \left(\beta_{i} X_{i}\right)
$$

The proportional event history model does not require specific assumptions with regards to the distribution of the hazard rate (Lancaster, 1992) and models time ( $t$-in this case, days since first confirmed infection case) as a function of an underlying hazard $h$ and a set of exponentiated beta coefficients $(\beta)$ and covariates $(X)$ for each country $i$ s adoption of policy $j$. The baseline hazard $h$ corresponds to the case where all covariates equal 0 , and is shifted up or down proportionally with changes in the covariates. The "time at risk" for each country begins when it reports its first case of Covid-19. Our analysis focuses on policy adoptions applicable for the entire country (see Table 1)—that is, the more "restrictive" versions of each policy. ${ }^{19}$ This allows us to model multiple-events data to examine the effects of countries' underlying level of electoral democracy and other background variables together with the time-variant variables influencing policy adoption. The event history model

\footnotetext{
18 Cepaluni et al. (2020) predict the death toll from Covid-19 in 106 countries using a dummy for countries having experienced 100+ confirmed cases of SARS in 2002-2003. In the OECD countries, only Canada had over 100 SARS cases. With remaining countries having six cases on average, this measure was non-applicable. ${ }^{19}$ In unreported models (available upon request) we include both "recommend" and "required" policies in the event history model, with close to identical results. Modeling only "recommended" policies reduces the explained variance by about $8-10 \%$ and effect sizes for all variables decrease, but remain statistically significant and meaningfully large for our two hypothesized effects.
} 
treats countries that never adopt any of the interventions as right-censored, and countries adopting polices before entering the risk set as left-censored. Appendix A presents descriptive statistics and variable correlations. ${ }^{20}$

${ }^{20}$ In a separate analysis (available upon request) we included a period effect corresponding to the World Health Organization's (WHO) global pandemic announcement (March 11, 2020) to control for the potential influence of this announcement on adoption rates. Inclusion of the period effect variable did not change any of the main results, but the variable was highly collinear to several of our adoption measures as well as control variables, and we therefore omit it from the main analysis. 


\section{Results}

Table 2 shows hazard ratios (exponentiated coefficients) obtained by the event history model predicting time to adoption of any Covid-19 policy among the OECD countries. ${ }^{21}$ As might be expected, countries with more healthcare capacity (hospital beds) are slower to adopt restrictions, as are countries with more unequal income distribution (i.e. higher GINI index). The more densely populated a country is, the faster it is to adopt restrictions.

Table 2. Marginal risk set model predicting adoption of Covid-19 policies

\begin{tabular}{|c|c|c|c|c|c|}
\hline \multirow[b]{2}{*}{ GDP per capita (log) } & (1) & (2) & (3) & (4) & (5) \\
\hline & $\begin{array}{l}0.274 \\
(0.230)\end{array}$ & $\begin{array}{l}0.247^{*} \\
(0.136)\end{array}$ & $\begin{array}{l}0.720 \\
(0.743)\end{array}$ & $\begin{array}{l}0.583 \\
(0.526)\end{array}$ & $\begin{array}{l}0.522 \\
(0.412)\end{array}$ \\
\hline Tax revenue (\% of GDP) & $\begin{array}{l}1.004 \\
(0.054)\end{array}$ & $\begin{array}{l}0.965 \\
(0.052)\end{array}$ & $\begin{array}{l}0.995 \\
(0.051)\end{array}$ & $\begin{array}{l}0.983 \\
(0.061)\end{array}$ & $\begin{array}{l}0.975 \\
(0.061)\end{array}$ \\
\hline GINI index (income) & $\begin{array}{l}0.844^{* *} \\
(0.052)\end{array}$ & $\begin{array}{l}0.830 * * \\
(0.055)\end{array}$ & $\begin{array}{l}0.816^{* *} \\
(0.056)\end{array}$ & $\begin{array}{l}0.807 * * \\
(0.056)\end{array}$ & $\begin{array}{l}0.802 * * \\
(0.060)\end{array}$ \\
\hline Hospital beds (/1,000 people) & $\begin{array}{l}0.743^{*} \\
(0.100)\end{array}$ & $\begin{array}{l}0.730^{*} \\
(0.100)\end{array}$ & $\begin{array}{l}0.753^{*} \\
(0.096)\end{array}$ & $\begin{array}{l}0.701^{*} \\
(0.104)\end{array}$ & $\begin{array}{l}0.680^{*} \\
(0.104)\end{array}$ \\
\hline Population age $\geq 65(\%)$ & $\begin{array}{l}0.877 \\
(0.089)\end{array}$ & $\begin{array}{l}0.875 \\
(0.074)\end{array}$ & $\begin{array}{l}0.944 \\
(0.087)\end{array}$ & $\begin{array}{l}0.940 \\
(0.095)\end{array}$ & $\begin{array}{l}0.938 \\
(0.084)\end{array}$ \\
\hline Urban population (\%) & $\begin{array}{l}0.978 \\
(0.029)\end{array}$ & $\begin{array}{l}0.994 \\
(0.028)\end{array}$ & $\begin{array}{l}0.976 \\
(0.028)\end{array}$ & $\begin{array}{l}0.982 \\
(0.029)\end{array}$ & $\begin{array}{l}0.988 \\
(0.031)\end{array}$ \\
\hline Population density (log) & $\begin{array}{l}1.923^{* * *} \\
(0.362)\end{array}$ & $\begin{array}{l}1.938^{* * *} \\
(0.329)\end{array}$ & $\begin{array}{l}1.940^{* * * *} \\
(0.351)\end{array}$ & $\begin{array}{l}2.006^{* * *} \\
(0.312)\end{array}$ & $\begin{array}{l}2.007^{* * *} \\
(0.302)\end{array}$ \\
\hline Death rate $\left(/ 100^{\prime}\right)$ & $\begin{array}{l}0.331 \\
(0.319)\end{array}$ & & & $\begin{array}{l}0.097+ \\
(0.132)\end{array}$ & $\begin{array}{l}0.087+ \\
(0.114)\end{array}$ \\
\hline \multicolumn{2}{|c|}{ Adoption density (OECD region) } & $\begin{array}{l}1.302^{* * *} \\
(0.087)\end{array}$ & & $\begin{array}{l}1.320^{* * *} \\
(0.103)\end{array}$ & $\begin{array}{l}0.471^{*} \\
(0.162)\end{array}$ \\
\hline \multicolumn{2}{|l|}{ Electoral democracy } & & $\begin{array}{l}0.921 * * \\
(0.029)\end{array}$ & $\begin{array}{l}0.939 * \\
(0.030)\end{array}$ & $\begin{array}{l}0.882^{* * *} \\
(0.016)\end{array}$ \\
\hline \multicolumn{3}{|c|}{ Adoption density X electoral democracy } & & & $\begin{array}{l}1.013^{* *} \\
(0.004)\end{array}$ \\
\hline Obse & 5,278 & 5,278 & 5,278 & 5,278 & 5,278 \\
\hline Numb & 36 & 36 & 36 & 36 & 36 \\
\hline Number of & 138 & 138 & 138 & 138 & 138 \\
\hline Pseudo-R-squared & 0.103 & 0.126 & 0.129 & 0.158 & 0.166 \\
\hline Log likelihood & -706.5 & -689.0 & -686.6 & -663.5 & -657.0 \\
\hline
\end{tabular}

\footnotetext{
${ }^{21}$ Efron methods are used to handle tied events. The proportional-hazard assumption is met in all models.
} 
Figure 3. Hazard ratios and confidence interval of adopting Covid-19 policies

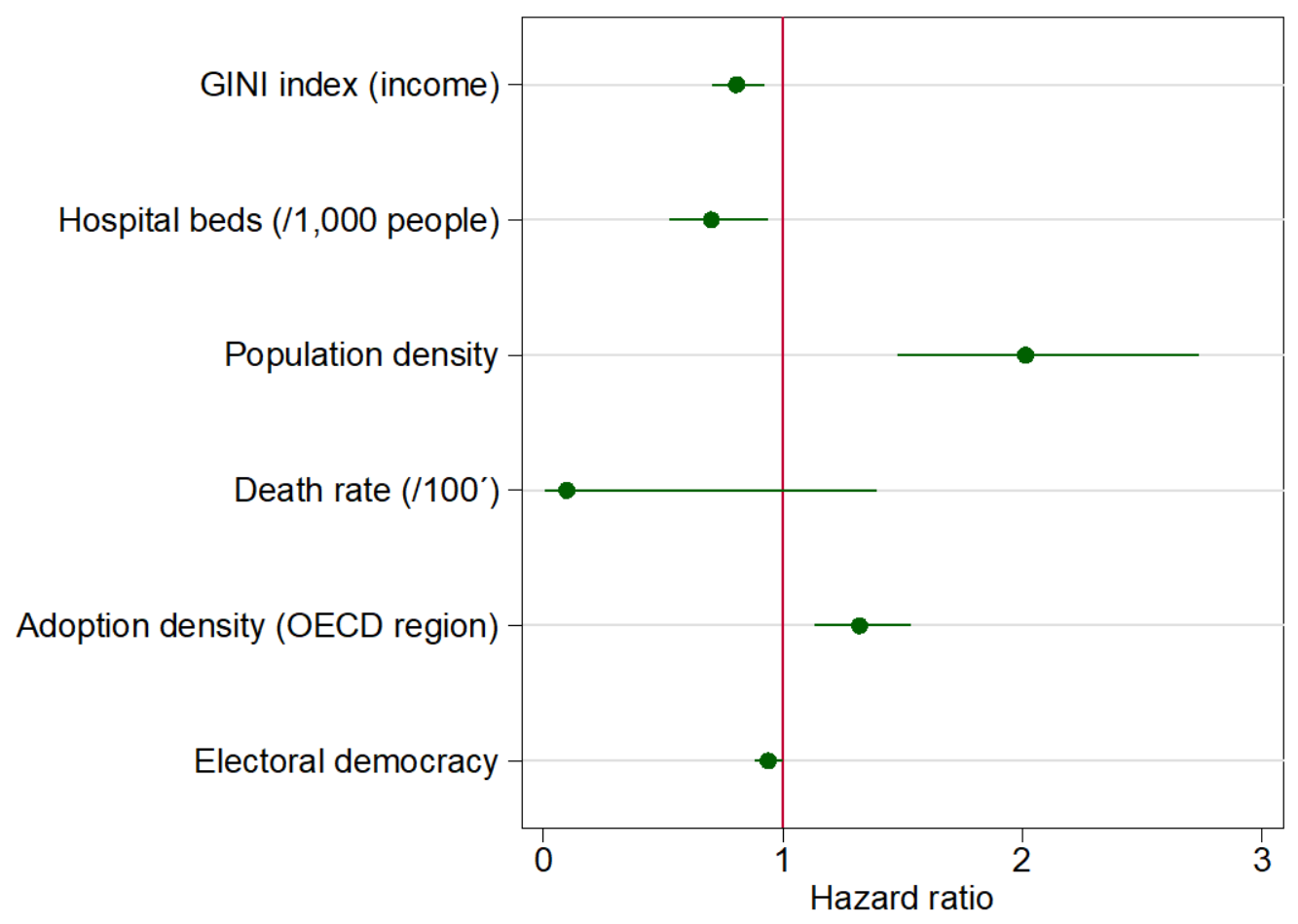

Plots of the key estimated hazard ratios (HRs) with 95\% confidence intervals are shown in Figure 3. Consistent with both hypotheses, we see that adoption density within the same OECD region predicts a more rapid rate of policy adoption, while a higher level of electoral democracy predicts a slower rate of policy adoption. Our null hypotheses of Adoption density (OECD region) and Electoral democracy not predicting adoption of Covid-19 policies are examined in column 4 of Table 2, which rejects the null for both Adoption density and Electoral democracy. Interestingly, we also see that the daily count of deaths in a country is a rather poor predictor of adopting Covid-19 NPIs, with a large confidence interval. One potential explanation for this effect is that the interventions adopted may take the form of preventive measures rather than reactions to the emergence of a national pandemic. We evaluate such measures further in the supplementary analysis in relation to the stringency of interventions adopted, showing death rate to be a strong predictor. The other two control variables for countries' healthcare capacity and demography (number of hospital beds and population density) predict a lower and a more rapid policy adoption, respectively. The effect of population density is by far the strongest predictor in the model, albeit with high standard errors due to the large between-country variation. 
The main conclusion from our event history model is thus that both hypotheses are supported: adoption density within the same OECD region predicts a much more rapid rate of policy adoption, while a higher level of electoral democracy predicts a slightly slower rate of policy adoption.

\section{Post-hoc test: Analyzing the adoption of specific interventions}

Since Figure 1 showed different speeds of adoption for the various Covid-19 NPIs, as well as the more generic policy of "public information campaigns" included in our analysis, it also interesting to examine these separately. Appendix B shows event history results for five individual NPI adoptions. Estimated hazard ratios from these separate event history models for each NPI are shown in Figure 4 with 95\% confidence intervals. ${ }^{22}$

Figure 4. Hazard ratios and confidence interval of specific Covid-19 policies

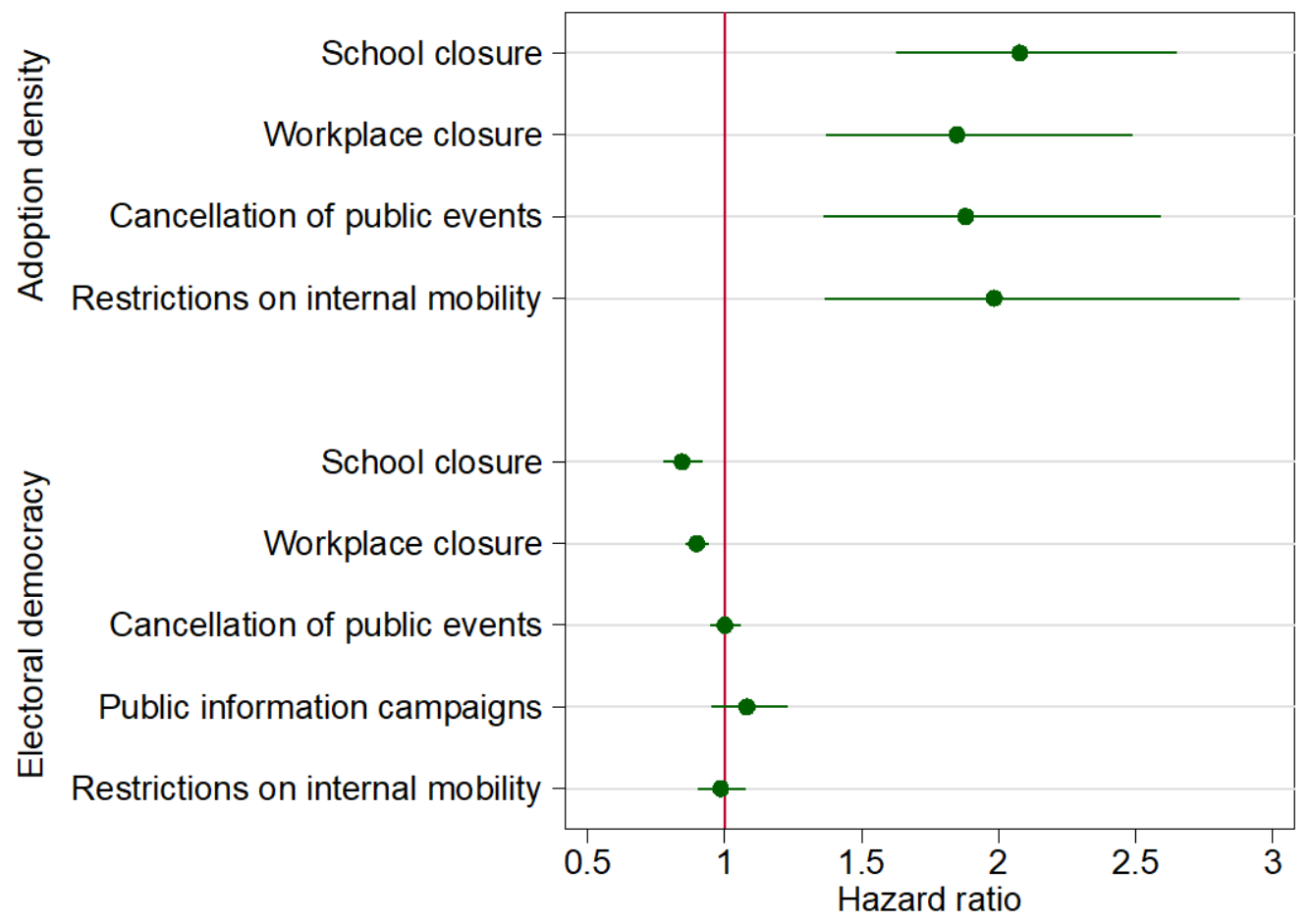

\footnotetext{
22 Since the death rate and population density variable exhibited even larger standard errors in the separate event history models, we exclude them from Figure 4 so as not to distort the visualization of results. The proportional-hazard assumption is met in all models except for "workplace closure" and "restrictions on internal mobility," where assumptions are met only if the two outliers in the electoral democracy index (Turkey and Hungary) are winsorized.
} 
Figure 4 shows that adoption density consistently predicts quicker adoption for each NPI, while electoral democracy predicts a slower time to adopt school and workplace closures. This provides further evidence for the general pattern revealed in the main analysis (marginal risk set model), and also indicates that the overall effect of electoral democracy on the speed by which OECD countries adopt Covid-19 policies examined in the marginal risk set model is primarily driven by more democratic countries being slower to adopt interventions related to school and workplace closures.

\section{Post-hoc test: does uncertainty tolerance drive the adoption rate?}

We here probe the specific argument of the policy diffusion theory with respect to other countries' earlier adoptions having more importance for a decision-maker if there is great uncertainty around the policy (Greve, 1995; J. G. March, 1994). We cannot accurately classify the specific interventions themselves as more or less uncertain, given the current lack of knowledge of the Covid-19 virus and epidemiological discussions regarding the uncertainty of NPIs (Ferguson et al., 2020; Ioannidis, 2020). However, we can examine variation in different countries' tolerance for uncertainty using other validated measures. We do so by adopting two of Hofstede's (1980) six dimensions of "national culture." 23 The two cultural dimensions are time-invariant variables measuring: i) uncertainty avoidance ("the degree to which the members of a society feel uncomfortable with uncertainty and ambiguity") and ii) long-term orientation ("the degree to which a society is long-term oriented dealing with current and future goals"). ${ }^{24}$ Adding these to the baseline marginal risk set model (Table 3) show that both variables predict the speed of policy adoption up and above the. Countries with a more uncertainty-avoidant culture are quicker to adopt Covid-19 NPIs (hazard ratio: $1.025, p<0.05)$, but those with a stronger long-term orientation are slower to adopt such interventions (hazard ratio: $0.952, p<0.05) .{ }^{25} \mathrm{We}$ also examined if countries' underlying

\footnotetext{
${ }^{23}$ Alternative measures of variation in country's national culture regarding uncertainty and decision-making from the World Value Survey (WVS) or the GLOBE survey were also examined but did not cover all countries in our data. Hofstede's other dimension of culture were not meaningfully related to countries' adoption rates. ${ }^{24}$ https://hi.hofstede-insights.com/national-culture

25 The hazard ratios indicate that countries with an uncertainty avoidance level one percentage point higher, on a scale from 23 to 100 (mean: 64.2), increase the speed of policy adoption by $2.5 \%$, while countries with a $1 \%$ higher level of long-term orientation on a scale from 21 to 100 (mean: 52.6) decrease the speed of policy adoption by $4.8 \%$.
} 
uncertainty avoidance affects the diffusion from proximate countries by interacting the two culture measures with the adoption density (OECD region) measure, but found no evidence of any such pattern (hazard ratios: $0.998, p>0.39$ and $p>0.39$, respectively).

\section{Post-hoc test: teasing out elements of the democratic structure and adoption}

Our hypotheses suggest that the context within which national leaders decide on the timing of interventions is influenced by the interventions undertaken by other, proximate countries, as well as the state of its own democracy. These two conditions could of course be contingent on each other. We argued that politicians in a more vibrant democracy face great uncertainty regarding citizens' reactions to far-reaching interventions entailing restrictions on their personal freedom (Sartori, 1987) and also that earlier adoptions can create a sense of security in the decision, in line with the notion of "safety in numbers" (Levitt \& March, 1988). Taken together, this suggests that more vibrant democracies would be more strongly affected by the density of earlier adoptions than would less vibrant democracies. We test this by plotting the effect of adoption density (OECD region) for countries with lower or higher levels of electoral democracy (below or above the sample mean) for adopting any of the five Covid-19 policies, shown below in Figure 5. 
Figure 5. Effects of proximate countries' policy adoption on the probability of countries with lower or higher levels of democracy adopting Covid-19 policies

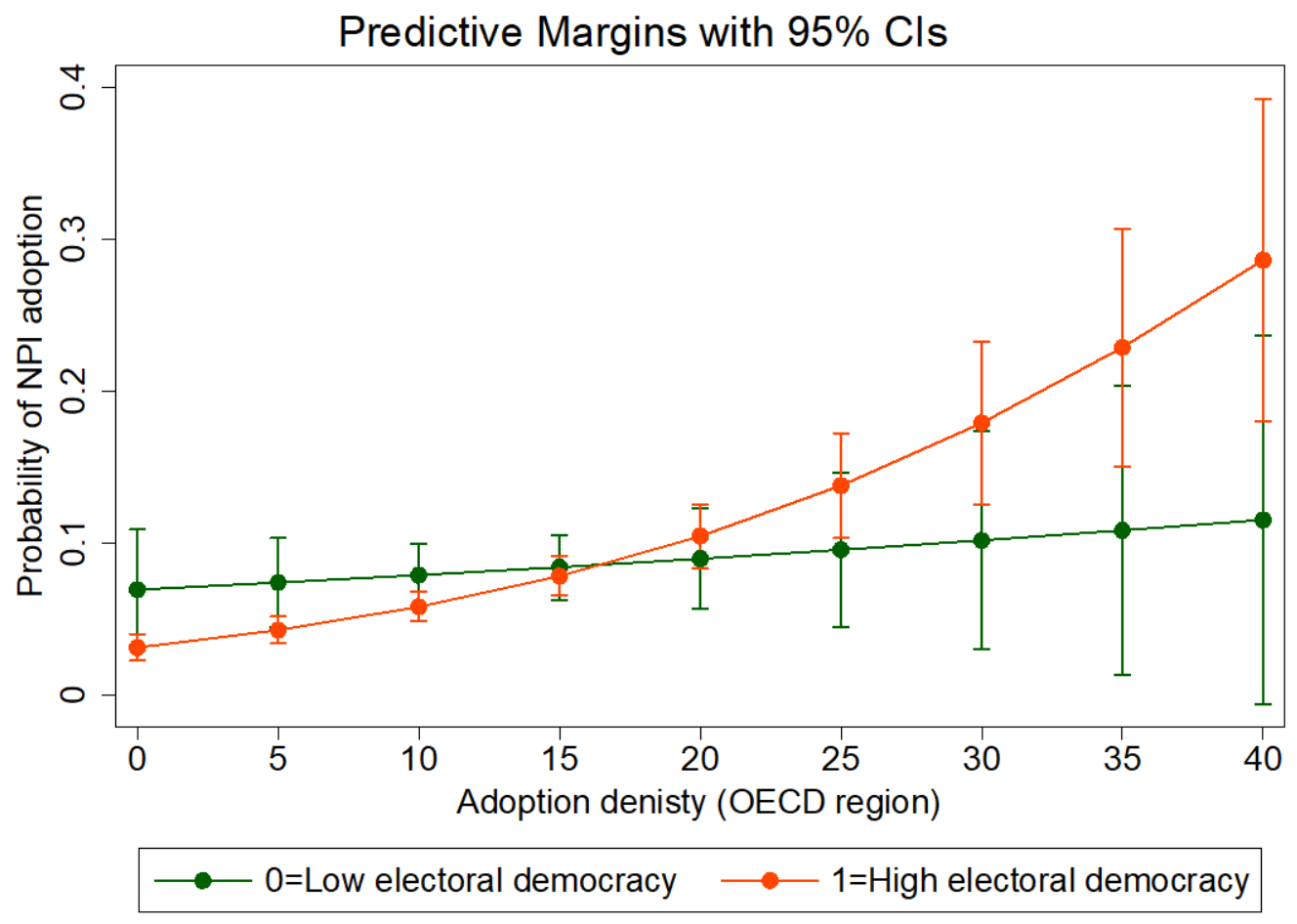

Figure 5 show that the two hypothesized effects are in fact contingent upon each other, but relatively weakly so. At low levels of other countries' adoption of Covid-19 policies, countries with more developed democratic institutions are relatively slower to adopt any of the policies in question, with a marginal decrease in adoption rate at about 4 to $5 \%$. At high levels of adoption density in the OECD region, however, countries with more developed democratic institutions seem to be relatively more rapid to adopt Covid-19 policies, however with large confidence intervals that overlap at 5 percent level of statistical significance.

As final scrutiny we turn to elements of democracy rather than the overarching index of electoral democracy. We select 10 underlying variables of the electoral democracy index from the V-Dem dataset, as well as one from the International Country Risk Guide (ICRG, 2019) and one from the Global State of Democracy Indices (GSoD, 2019). ${ }^{26}$ We replace electoral democracy with these variables in our main model and estimate them separately. The effect of each these elements of democracy uniformly points in the same direction, i.e.,

26 'Head of government removal by legislature', 'Executive respects constitution', 'Executive oversight', 'Civil service organization (CSO) consultation', 'CSO participatory environment', 'Impartial administration', 'Rigorous and impartial administration', 'bureaucratic quality' (ICRG), and 'effective parliament' (GSoD). 
countries were slower to adopt a policy if they had higher quality on a specific democratic element. Appendix E plots a selection of these results. We also interacted each of these variables with regional adoption density. Only one variable was contingent on the level regional adoption density akin to the pattern for electoral democracy shown in Figure 5, 'rigorous and impartial administration' (see Appendix E, Figure E2).

\section{Post-hoc test: analyzing the stringency of interventions adopted}

In a second set of supplementary analyses, we use the Oxford Covid-19 Government Response Tracker (OxCGRT) database (Table 1) stringency index as our dependent variable (Hale et al., 2020). The stringency index in this case is an additive unweighted index ranging from $0-100$, where higher values indicate a larger number of measures implemented in a stricter manner by a country to counteract the Covid-19 pandemic. ${ }^{27}$ The variable accounts for the severity of interventions by coding each policy on ordinal scales. This analysis thus sheds light on the factors influencing the comprehensiveness of the Covid-19 NPIs that countries undertake, rather than the speed at which they adopt them. Appendix $C$ presents descriptive statistics and variable correlations. We assess the stringency of Covid-19 NPIs by regressing the stringency index of the OxCGRT using panel data generalized least squares (GLS) model with random effects:

$$
y_{i t}=\alpha+\beta_{2} \operatorname{democracy}_{i}+X_{i} \beta+\varepsilon_{i}
$$

Where $y_{i t}$ represents the stringency index for country $i$ in time $t$ (in days since the first confirmed infection case), $\beta_{1}$ is the beta coefficient of the key time-invariant variable of electoral democracy index to be estimated, $X_{i}$ represent a vector of time-invariant control variables to be estimated, and $\varepsilon_{i}$ is the error term. ${ }^{28}$

\footnotetext{
27 The index is a score generated by taking the ordinal value and adding 1 if the policy is general rather than targeted, if applicable. This creates a score between 0 and 2 for S5, and 0 and 3 for the other six responses. The variable is then rescaled by its maximum value to create a score between $0-100$, with a missing value defaulting to 0 . These seven scores are then averaged (Hale et al. 2020).

${ }^{28}$ Four OECD countries are missing from the stringency index (Estonia, Lithuania, Luxembourg, and Latvia), since they did not adopt any NPIs during the observation period. We set the stringency index to 0 for these countries. Exclusion of these countries from the OLS analysis did not alter any of the main results reported.
} 
Table 3. Predicting the stringency of Covid-19 policies in OECD countries

\begin{tabular}{llll}
\hline & $(1)$ & $(2)$ & $(3)$ \\
\hline GDP per capita (log) & -3.715 & 4.445 & 3.457 \\
Tax revenue (\% of GDP) & $(7.339)$ & $(6.759)$ & $(7.239)$ \\
& -0.041 & -0.162 & -0.081 \\
GINI index (income) & $(0.580)$ & $(0.541)$ & $(0.553)$ \\
& -0.776 & -0.815 & -0.814 \\
Hospital beds (/1,000 people) & $(0.672)$ & $(0.601)$ & $(0.618)$ \\
& 0.527 & -0.424 & 0.091 \\
Population age $\geq 65(\%)$ & $(1.386)$ & $(1.314)$ & $(1.310)$ \\
& $-1.741^{*}$ & -0.711 & -0.821 \\
Urban population $(\%)$ & $(0.773)$ & $(0.754)$ & $(0.788)$ \\
& 0.022 & 0.046 & 0.009 \\
Population density (log) & $(0.274)$ & $(0.253)$ & $(0.245)$ \\
& $5.372^{* *}$ & $5.905 * * *$ & $4.719 *$ \\
Death rate (/100') & $(2.055)$ & $(1.792)$ & $(1.844)$ \\
& $11.701 * *$ & & $11.706^{* *}$ \\
Electoral democracy & $(3.615)$ & & $(3.610)$ \\
Constant & & $-0.709^{* * *}$ & $-0.748^{* * *}$ \\
& & $(0.193)$ & $(0.200)$ \\
\hline Observations & 98.528 & 58.126 & 75.504 \\
Number of countries & $(87.690)$ & $(76.766)$ & $(83.036)$ \\
R-square & 1,356 & 1,356 & 1,356 \\
Model chi-square & 36 & 36 & 36 \\
Root MSE & 0.208 & 0.128 & 0.240 \\
\hline
\end{tabular}

Note: Models specified as GLS Panel models with random effects. Stringency of policy adoption and death rate updated daily, all other variables constant. Measured daily January 15-March 30 2020. Standard errors in parentheses are clustered at the country level. ${ }^{* * *} \mathrm{p}<0.001,{ }^{* *} \mathrm{p}<0.01,{ }^{*} \mathrm{p}<0.05,+\mathrm{p}<0.10$

The result of our GLS panel model predicting the stringency of Covid-19 policies in OECD countries is shown in Table 3. We examine each independent variable by inserting them hierarchically to avoid collinearity. ${ }^{29}$

The coefficients of Table 3 show that the epidemiological baseline indicator (death rate) now strongly predicts the stringency of countries' policy adoptions (stringency index), as does population density. A stronger electoral democracy, on the other hand, weakens the stringency of measures adopted. Looking across the analysis of timing of adoption and stringency of adoption, we see that population density predicts policy adoptions as well as stringency of policies. A higher score on the democracy index, on the other hand, predicts slower as well as less stringent adoption of NPIs. ${ }^{30}$

\footnotetext{
29 The Multicollinearity diagnostic Variance Inflation Factor (VIF) was below 2 for all models.

30 As noted in Figure 2, there are two outliers in the electoral democracy variable. Winsorizing electoral democracy $5 \%$ in the lower and upper tail of the distribution did not change the results.
} 


\section{Post-hoc test: political-institutional structure vs. political ideology?}

Given the unambiguous results that countries with a higher level of electoral democracy are slower to adopt Covid-19 NPIs (see also Cepaluni, Dorsch, \& Branyiczki, 2020), and that they are also less susceptible to be influenced by the adoption rates of proximate countries, one may ask whether such policy emulation is politically or normatively driven. In a similar paper modeling time to adoption for five different social-distancing interventions among US States, Adolph et al. (2020) highlight the political nature of within-US policy diffusion by showing how Republican governors, and governors from states with more Trump supporters, were slower to adopt social-distancing interventions. To distinguish the influence of political structure (level of electoral democracy) from that of political ideology, we therefore examined Adolph et al.'s thesis of policy emulation as a politically driven process by including a coefficient measuring the politically dominant party or party group in each country as 'right-leaning', 'left-leaning', or 'mixed' from the European Consortium for Political Research's Political Data Yearbook (Clark \& Meijers, 2019). ${ }^{31}$ The coefficient from this variable only marginally affected the speed of policy diffusion in our main model specification (hazard ratio: $0.483, p<0.05$ ) and dot not alter the effects of 'adoption density' nor 'electoral democracy', lending credence to our conclusions that the diffusion of Covid19 NPIs across OECD countries takes the form of a normative diffusion process affected by variations in electoral democracy, rather than a political diffusion process as indicated in the U.S. (Adolph et al., 2020).

As a final examination of the effects of institutional variations potentially related to variations in electoral democracy, we explored standard indicators of "government effectiveness" and "bureaucratic quality" from the World Bank. Both variables were weakly negatively related to the speed of adopting Covid-19 policies in the OECD but with high standard errors, and neither of them were statistically significant.

31 32/34 OECD countries were pre-coded and 2 were coded by country experts, with 11 countries 'rightleaning' (coded as 1), 12 'left-leaning' (coded as -1), and 13 'mixed' (coded as 0). 


\section{Discussion}

Almost eighty percent of the OECD countries adopted the same Covid-19 NPIs within a span of two weeks. If adoption was the result of a decision process that took the specific situation of heterogeneous countries into account, why do we see such homogeneity? One answer would be that the countries were all exposed to the same universal threat. However, our findings suggest that this is probably not the true cause. With the exception of population density, it is not primarily the needs of the country in terms of exposure to Covid-19, demographic structure, or healthcare capacity that predict the speed of adopting NPIs, but the number of earlier adopters in the same region. Countries with stronger democracies are slower to react in the face of the pandemic and less stringent in the number and type of policies adopted over time, but more sensitive to the influence of many other countries adoptions and more.

Our findings inform current discussions in public health research, political science, and international relations. Much of the debate around the various types of NPIs in public health and related research has focused on whether or not a country needs a particular policy to protect its citizens' public health; little attention has been paid to the timing of policy intervention. While we admit that we have absolutely no way of judging what an 'optimal' adoption timing would be for any country, it follows from our findings of what appears to be inter-national mimicry of intervention adoption that some countries may have adopted restrictive measures rather sooner than necessary. If that is the case, these countries may have incurred unnecessarily high social and economic costs, and it may also be problematic to sustain the restrictions for as long as is necessary, due to lockdown fatigue.

Political scientists, international relations scholars as well as public health scholars may also benefit from building on our model suggesting the adoption of Covid-19 policies across the OECD countries to be driven by consideration of what others have done. For example, it is likely that rescinding such interventions would also follow that kind of pattern (Greve, 1995). Abandoning containment measures too early, or too late, are also uncertain decisions that risks undermining the efficiency and efficacy of interventions taken (Davies et al., 2020; Ferguson et al., 2020). As much of Europe and North America is following this route of "de-escalation" as of early May 2020, future research may extend our data (open to the public) to examine both adoption, 'de-escalation', and potential 're-adoption' of Covid19 policies. Such research may also seek to collect e.g. social network data or other data to 
gauge the underlying causal mechanisms of Covid-19 policy diffusion in terms of 'learning', 'emulation', or 'coercion' between across nation-states (Shipan \& Volden, 2012).

Finally, our analysis of the timing of Covid-19 policies can inform contemporary political science research on the consequences of exogenous events such as pandemics. Our analysis reveals that countries with strong electoral democracy are slower in adopting Covid19 policies to slow the spread of the virus, but also that these countries are more susceptible to the diffusion pressure of many proximate countries adopting such policies. If restrictions in civil liberties due to the ongoing Covid-19 pandemic are more rapidly adopted by countries already experiencing a decline in democracy, this indicates that such countries are susceptible to further autocratization in face of exogenous chocks such as pandemics. For example, recent evidence from Spain suggests that the pandemic may have caused the population to look more favorably on technocratic and authoritarian government (Amat et al., 2020). Our study provides fertile ground for social and behavioral research on the impact of the Covid-19 pandemic, which to date has merely begun to grapple with the pandemic's short-term effects (Van Bavel et al., 2020). In particular, issues such as the effect of specific NPIs, their duration, and whether they are repeated over longer periods are all relevant for key political science topics such as civil engagement, interpersonal trust, belief in authorities, and democratic practices. Economic research exploring the potential effects of NPIs as well as interventions aimed at mitigating the recession in the wake of the pandemic (CEPR, 2020), may also utilize these findings by incorporating potential setbacks in democratic development as potential externalities related to unconventional interventions.

\section{References}

Adolph, C., Amano, K., Bang-Jensen, B., Fullman, N., \& Wilkerson, J. (2020). Pandemic Politics: Timing State-Level Social Distancing Responses to COVID-19. medRxiv, bttps:// doi.org/ 10.1101/2020.03.30.20046326.

Ahmadjian, C. L., \& Robinson, P. (2001). Safety in Numbers: Downsizing and the Deinstitutionalization of Permanent Employment in Japan. Administrative Science Quarterly, 46(4), 622-654.

Amat, F., Arenas, A., Falcó-Gimeno, A., \& Muñoz, J. (2020). Pandemics meet democracy. Experimental evidence from the COVID-19 crisis in Spain. SocArXiv. April, 6.

Anderson, R. M., Heesterbeek, H., Klinkenberg, D., \& Hollingsworth, T. D. (2020). How will country-based mitigation measures influence the course of the COVID-19 epidemic? The Lancet, 395(10228), 931-934. 
Bader, J., Grävingholt, J., \& Kästner, A. (2010). Would autocracies promote autocracy? A political economy perspective on regime-type export in regional neighbourhoods. Contemporary Politics, 16(1), 81-100.

Besley, T., \& Kudamatsu, M. (2006). Health and democracy. American Economic Review, 96(2), 313-318.

Brinks, D., \& Coppedge, M. (2006). Diffusion is no illusion: Neighbor emulation in the third wave of democracy. Comparative Political Studies, 39(4), 463-489.

Briscese, G., Lacetera, N., Macis, M., \& Tonin, M. (2020). Compliance with covid-19 socialdistancing measures in italy: the role of expectations and duration (0898-2937). Retrieved from

Cepaluni, G., Dorsch, M., \& Branyiczki, R. (2020). Political Regimes and Deaths in the Early Stages of the COVID-19 Pandemic. Available at SSRN 3586767.

CEPR. (2020). Mitigating the COVID Economic Crisis: Act Fast and Do Whatever it Takes. In R. Baldwin \& B. W. d. Mauro (Eds.).

Clark, A., \& Meijers, M. (2019). Political Data in 2018: Introducing the 2018 Political Data Yearbook. European Journal of Political Research Political Data Yearbook, 58(1), 3-11. doi:10.1111/2047-8852.12271

Coppedge, M., Gerring, J., Knutsen, C. H., Lindberg, S. I., Teorell, J., Marquardt, K. M., . . . Gastaldi, L. (2020). Methodology V10.

Dahl, R. (1971). Polyarchy. New Haven, CT: Yale University Press.

Dahl, R. A. (1989). Democracy and its Critics: Yale University Press.

Dahl, R. A. (2008). On democracy: Yale university press.

Davies, N. G., Kucharski, A. J., Eggo, R. M., Gimma, A., Edmunds, W. J., \& Group, C. C.W. (2020). The effect of non-pharmaceutical interventions on COVID-19 cases, deaths and demand for hospital services in the UK: a modelling study. MedRxiv, bttps:// doi.org/10.1101/2020.04.01.20049908.

Diamond, L. (2002). Elections without democracy: Thinking about hybrid regimes. Journal of Democracy, 13(2), 21-35.

El Zein, M., Bahrami, B., \& Hertwig, R. (2019). Shared responsibility in collective decisions. Nature Human Behaviour, 3(6), 554-559. doi:10.1038/s41562-019-0596-4

Ferguson, N., Laydon, D., Nedjati Gilani, G., Imai, N., Ainslie, K., Baguelin, M., . . . Cuomo-Dannenburg, G. (2020). Report 9: Impact of non-pharmaceutical interventions (NPIs) to reduce COVID19 mortality and healthcare demand. Imperial College London. https://spiral.imperial.ac.uk/handle/10044/1/77482.

Flaxman, S., Mishra, S., \& Gandy, A. (2020). Estimating the number of infections and the impact of nonpharmaceutical interventions on COVID-19 in 11 European countries. Imperial College London COVID-19 Reports. Retrieved from

Foreign Policy. (2020). Don't Let Leaders Use the Coronavirus as an Excuse to Violate Civil Liberties. Foreign Policy, April 13. Retrieved from https://foreignpolicy.com/2020/04/13/governments-coronavirus-pandemic-civilliberties/

Gavazzi, G., \& Krause, K.-H. (2002). Ageing and infection. The Lancet infectious diseases, 2(11), 659-666.

Gleditsch, K. S., \& Ward, M. D. (2006). Diffusion and the international context of democratization. International organization, 60(4), 911-933.

Greve, H. R. (1995). Jumping ship: The diffusion of strategy abandonment. Administrative Science Quarterly, 444-473.

GSoD. (2019). The Global State of Democracy Indices. Retrieved from: https://www.idea.int/gsod-indices/dataset-resources 
Hale, T., Petherick, A., Phillips, T., \& Webster, S. (2020). Variation in Government Responses to COVID-19, Version 4.0. Blavatnik School of Government Working Paper. April 7, 2020. Available: www.bsg.ox.ac.uk/ covidtracker. Retrieved from

Hauck, K. (2018). The Economics of Infectious Diseases. In Oxford Research Encyclopedia of Economics and Finance.

Haunschild, P. R., \& Miner, A. S. (1997). Modes of interorganizational imitation: The effects of outcome salience and uncertainty. Administrative Science Quarterly, 472-500.

Hofstede, G. (1980). Culture's Consequences: International Differences in Work Related Values. Beverly Hills, California: Sage Publications.

Houle, C., \& Kayser, M. A. (2019). The Two-step Model of Clustered Democratization. Journal of Conflict Resolution, 63(10), 2421-2437.

ICRG. (2019). International Country Risk Guide (ICRG). Retrieved from: https://www.idea.int/gsod-indices/dataset-resources

Ioannidis, J. P. A. (2020). Coronavirus disease 2019: The harms of exaggerated information and non-evidence-based measures. European Journal of Clinical Investigation, 50(4), e13222. doi:10.1111/eci.13222

Jefferson, T., Del Mar, C. B., Dooley, L., Ferroni, E., Al-Ansary, L. A., Bawazeer, G. A., . . . Thorning, S. (2011). Physical interventions to interrupt or reduce the spread of respiratory viruses. Cochrane database of systematic reviews, 7, CD006207.

Karlson, N., Stern, C., \& Klein, D. (2020). Sweden's Coronavirus Strategy Will Soon Be the World's. Foreign Affairs, May 12, 2020, https:/ / www.foreignaffairs.com/articles/sweden/2020-05-12/ swedens-coronavirus-strategy-willsoon-be-worlds.

Katz, E., Levin, M. L., \& Hamilton, H. (1963). Traditions of research in the diffusion of innovation. American Sociological Review, 28(2), 237-252.

Lancaster, T. (1992). The econometric analysis of transition data: Cambridge university press.

Leeson, P. T., \& Dean, A. M. (2009). The democratic domino theory: An empirical investigation. American Journal of Political Science, 53(3), 533-551.

Levitsky, S., \& Way, L. A. (2006). Linkage versus leverage. Rethinking the international dimension of regime change. Comparative Politics, 379-400.

Levitt, B., \& March, J. G. (1988). Organizational learning. Annual Review of Sociology, 14, 319340.

Mainwaring, S., \& Pérez-Liñán, A. (2013). Democracies and dictatorships in Latin America: emergence, survival, and fall: Cambridge University Press.

March, \& Olsen. (2013). The Logic of Appropriateness. In R. E. Goodin (Ed.), The Oxford Handbook of Political Science (Vol. The Oxford Handbook of Political Science pp. DOI: 10.1093/oxfordhb/9780199604456.9780199604013.9780199600024): Oxford University Press.

March, J. G. (1994). Primer on decision making: How decisions happen: Simon and Schuster.

March, J. G., \& Olsen, J. P. (1975). The Uncertainty of the Past: Organizational Learning Under Ambiguity. European Journal of Political Research, 3(2), 147-171.

March, J. G., \& Olsen, J. P. (1976). Ambiguity and choice in organizations Universitetsforlaget. Bergen, Norway.

NYT. (2020). 64,000 Missing Deaths: Tracking the True Toll of the Coronavirus Outbreak. New York Times, accessed May 11th 2020. bttps:/ / www.nytimes.com/interactive/2020/04/21/world/ coronavirus-missing-deatbs. btml. 
O'Donnell, G. A. (1998). Horizontal accountability in new democracies. Journal of Democracy, 9(3), 112-126.

O'loughlin, J., Ward, M. D., Lofdahl, C. L., Cohen, J. S., Brown, D. S., Reilly, D., . . Shin, M. (1998). The diffusion of democracy, 1946-1994. Annals of the Association of American Geographers, 88(4), 545-574.

Persson, T. A., \& Povitkina, M. (2017). "Gimme shelter": The role of democracy and institutional quality in disaster preparedness. Political Research Quarterly, 70(4), 833-847.

Przeworski, A., Stokes, S. C. S., Stokes, S. C., \& Manin, B. (1999). Democracy, accountability, and representation (Vol. 2): Cambridge University Press.

Qi, Y., Du, C. D., Liu, T., Zhao, X., \& Dong, C. (2020). Experts' conservative judgment and containment of COVID-19 in early outbreak. Journal of Chinese Governance, 1-20.

Rogers, E. (1995). The diffusion of innovations. New York: The Free Press.

Rose-Ackerman, S. (1996). Democracy and 'grand'corruption. International social science journal, 48(149), 365-380.

Sartori, G. (1987). The theory of democracy revisited (Vol. 1): Chatham House Pub.

Shipan, C. R., \& Volden, C. (2008). The mechanisms of policy diffusion. American Journal of Political Science, 52(4), 840-857.

Shipan, C. R., \& Volden, C. (2012). Policy diffusion: Seven lessons for scholars and practitioners. Public Administration Review, 72(6), 788-796.

Simmons, B. A., \& Elkins, Z. (2004). The globalization of liberalization: Policy diffusion in the international political economy. American political science review, 98(1), 171-189.

Strang, D., \& Soule, S. A. (1998). Diffusion in organizations and social movements: From hybird corn to poison pills. Annual Review of Sociology, 24, 265-290.

Teorell, J., Coppedge, M., Lindberg, S., \& Skaaning, S.-E. (2019). Measuring polyarchy across the globe, 1900-2017. Studies in Comparative International Development, 54(1), 71-95.

Tetlock, P. (1996). Counterfactual thought experiments in world politics: Logical, methodological, and psychological perspectives: Princeton University Press.

Tolbert, P. S., \& Zucker, L. G. (1983). Institutional sources of change in the formal structure of organizations: the diffusion of civil service reform. Administrative Science Quarterly, 28, 22-39.

Van Bavel, J. J., Baicker, K., Boggio, P. S., Capraro, V., Cichocka, A., Cikara, M., . . . Druckman, J. N. (2020). Using social and behavioural science to support COVID-19 pandemic response. Nature Human Behaviour, 1-12, https://doi.org/10.1038/s4156241020-40884-Z.

Wang, H., Wang, Z., Dong, Y., Chang, R., Xu, C., Yu, X., .. . Huang, J. (2020). Phaseadjusted estimation of the number of coronavirus disease 2019 cases in Wuhan, China. Cell discovery, 6(1), 1-8.

Wei, L.-J., Lin, D. Y., \& Weissfeld, L. (1989). Regression analysis of multivariate incomplete failure time data by modeling marginal distributions. Journal of the American statistical Association, 84(408), 1065-1073.

Wejnert, B. (2002). Integrating Models of Diffusion of Innovations: A Conceptual Framework. Annual Review of Sociology, 28, 297-324.

WHO. (2020). Director-general's opening remarks at the media briefing on Covid-19. March 11th 2020. https:// www.who.int/dg/speeches/detail/who-director-general-s-opening-remarks-atthe-media-briefing-on-covid-19--11-march-2020.

Williams, A. (2015). A global index of information transparency and accountability. Journal of Comparative Economics, 43(3), 804-824. 
Wilson, M. C., Morgan, R. K., Medzihorsky, J., Maxwell, L., Maerz, S. F., Lührmann, A., . . . Lindberg, S. I. (2020). Successful and Failed Episodes of Democratization: Conceptualization, Identification, and Description. V-Dem Working Paper, 97.

Woodberry, R. D. (2012). The missionary roots of liberal democracy. American political science review, 106(2), 244-274. 


\section{Appendix A: Variable descriptives, main analyses (Table 2)}

Table A1. Event history analysis data, descriptive statistics and correlation matrix

\begin{tabular}{|c|c|c|c|c|c|c|c|c|c|}
\hline & & Mean & S.D. & Min & Max & 1 & 2 & 3 & 4 \\
\hline 1 & Policy adoption & 0.040 & 0.259 & 0 & 2 & & & & \\
\hline 2 & GDP per capita (log) & 10.587 & 0.516 & 9.145 & 11.667 & -0.033 & & & \\
\hline 3 & Tax revenue ( $\%$ of GDP) & 19.631 & 5.954 & 9.633 & 33.369 & 0.017 & 0.108 & & \\
\hline 4 & GINI index (income) & 33.081 & 4.661 & 24.200 & 45.4 & -0.018 & -0.265 & -0.335 & \\
\hline 5 & Hospital beds (/1,000 people) & 4.854 & 2.748 & 1.500 & 13.4 & 0.000 & -0.100 & -0.290 & -0.281 \\
\hline 6 & Population age $\geq 65(\%)$ & 18.170 & 3.707 & 7.224 & 27.576 & -0.019 & 0.092 & 0.038 & -0.447 \\
\hline 7 & Urban population $(\%)$ & 80.101 & 9.855 & 53.726 & 98.001 & -0.020 & 0.413 & 0.150 & 0.073 \\
\hline 8 & Population density (log) & 4.182 & 1.481 & 1.178 & 6.272 & 0.063 & -0.152 & -0.034 & -0.028 \\
\hline 9 & Death rate $\left(/ 100^{\prime}\right)$ & 0.063 & 0.412 & 0 & 13.979 & 0.013 & 0.089 & 0.032 & 0.015 \\
\hline 10 & Infection rate $\left(/ 100^{\prime}\right)$ & 6.703 & 26.365 & 0 & 325 & 0.000 & 0.218 & 0.113 & -0.071 \\
\hline 11 & Adoption density (OECD region) & 1.567 & 2.185 & 0 & 9 & 0.168 & -0.049 & 0.170 & 0.012 \\
\hline 12 & Electoral democracy & 82.999 & 8.235 & 29.200 & 90 & -0.071 & 0.503 & 0.172 & -0.366 \\
\hline \multirow[t]{2}{*}{13} & $\begin{array}{l}\text { Adoption density X } \\
\text { electoral democracy }\end{array}$ & 128.317 & 182.495 & 0 & 802.8 & 0.154 & 0.011 & 0.182 & -0.025 \\
\hline & & 5 & 6 & 7 & 8 & 9 & 10 & 11 & 12 \\
\hline 1 & Policy adoption & & & & & & & & \\
\hline 2 & GDP per capita (log) & & & & & & & & \\
\hline 3 & Tax revenue ( $\%$ of GDP) & & & & & & & & \\
\hline 4 & GINI index (income) & & & & & & & & \\
\hline 5 & Hospital beds (/1,000 people) & & & & & & & & \\
\hline 6 & Population age $\geq 65(\%)$ & 0.445 & & & & & & & \\
\hline 7 & Urban population $(\%)$ & -0.050 & -0.068 & & & & & & \\
\hline 8 & Population density (log) & 0.477 & 0.212 & -0.065 & & & & & \\
\hline 9 & Death rate $\left(/ 100^{\prime}\right)$ & -0.042 & -0.028 & 0.037 & 0.051 & & & & \\
\hline 10 & Infection rate $\left(/ 100^{\prime}\right)$ & -0.037 & -0.114 & 0.092 & -0.029 & 0.582 & & & \\
\hline 11 & Adoption density (OECD region) & -0.047 & -0.107 & -0.160 & 0.016 & 0.222 & 0.437 & & \\
\hline 12 & Electoral democracy & -0.016 & 0.402 & 0.148 & -0.121 & 0.061 & 0.086 & -0.099 & \\
\hline 13 & $\begin{array}{l}\text { Adoption density X } \\
\text { electoral democracy }\end{array}$ & -0.042 & -0.060 & -0.147 & 0.003 & 0.236 & 0.460 & 0.987 & 0.028 \\
\hline
\end{tabular}




\section{Appendix B: Post-hoc test analyzing adoption of specific interventions}

Separate event history models were used to model five ${ }^{32}$ of the six general Covid-19 NPIs described in Table 1. Descriptive statistics (available upon request) are very similar to those presented in Appendix A. The data is organized as single spell failure-time and estimated using semi-parametric cox proportional event history model, with results outlined below in Table B1.

Table B1. Cox proportional hazards model of adopting Covid-19 policies

\begin{tabular}{|c|c|c|c|c|c|}
\hline & $\begin{array}{c}(1) \\
\text { School } \\
\text { closure }\end{array}$ & $\begin{array}{c}(2) \\
\text { Workplace } \\
\text { closure }\end{array}$ & $\begin{array}{c}\text { (3) } \\
\text { Cancellation } \\
\text { of public } \\
\text { events }\end{array}$ & $\begin{array}{c}\text { (4) } \\
\text { Public } \\
\text { information } \\
\text { campaigns }\end{array}$ & $\begin{array}{c}(5) \\
\text { Restrictions } \\
\text { on internal } \\
\text { mobility }\end{array}$ \\
\hline GDP per capita (log) & $\begin{array}{l}0.243+ \\
(0.206)\end{array}$ & $\begin{array}{l}1.289 \\
(1.373)\end{array}$ & $\begin{array}{l}0.480 \\
(0.342)\end{array}$ & $\begin{array}{l}0.061+ \\
(0.096)\end{array}$ & $\begin{array}{l}0.289 \\
(0.412)\end{array}$ \\
\hline Tax revenue ( $\%$ of GDP) & $\begin{array}{l}0.918 \\
(0.060)\end{array}$ & $\begin{array}{l}0.957 \\
(0.060)\end{array}$ & $\begin{array}{l}0.978 \\
(0.064)\end{array}$ & $\begin{array}{l}0.751 \\
(0.162)\end{array}$ & $\begin{array}{l}0.933 \\
(0.099)\end{array}$ \\
\hline GINI index (income) & $\begin{array}{l}0.623^{* *} \\
(0.090)\end{array}$ & $\begin{array}{l}0.911 \\
(0.077)\end{array}$ & $\begin{array}{l}0.949 \\
(0.063)\end{array}$ & $\begin{array}{l}0.776^{*} \\
(0.093)\end{array}$ & $\begin{array}{l}0.990 \\
(0.105)\end{array}$ \\
\hline Hospital beds (/1,000 people) & $\begin{array}{l}0.753+ \\
(0.113)\end{array}$ & $\begin{array}{l}0.709 \\
(0.198)\end{array}$ & $\begin{array}{l}0.995 \\
(0.094)\end{array}$ & $\begin{array}{l}1.484^{*} \\
(0.256)\end{array}$ & $\begin{array}{l}0.801 \\
(0.164)\end{array}$ \\
\hline Population age $\geq 65(\%)$ & $\begin{array}{l}0.939 \\
(0.121)\end{array}$ & $\begin{array}{l}1.006 \\
(0.141)\end{array}$ & $\begin{array}{l}1.001 \\
(0.094)\end{array}$ & $\begin{array}{l}0.634^{*} \\
(0.146)\end{array}$ & $\begin{array}{l}1.200^{*} \\
(0.110)\end{array}$ \\
\hline Urban population (\%) & $\begin{array}{l}0.965 \\
(0.028)\end{array}$ & $\begin{array}{l}0.981 \\
(0.065)\end{array}$ & $\begin{array}{l}0.990 \\
(0.024)\end{array}$ & $\begin{array}{l}1.231 * \\
(0.101)\end{array}$ & $\begin{array}{l}1.035 \\
(0.063)\end{array}$ \\
\hline Population density (log) & $\begin{array}{l}1.934 * * \\
(0.461)\end{array}$ & $\begin{array}{l}1.492+ \\
(0.325)\end{array}$ & $\begin{array}{l}1.453+ \\
(0.304)\end{array}$ & $\begin{array}{l}1.055 \\
(0.226)\end{array}$ & $\begin{array}{l}1.967^{*} \\
(0.632)\end{array}$ \\
\hline Death rate $\left(/ 100^{\prime}\right)$ & $\begin{array}{l}3.074 \\
(3.404)\end{array}$ & $\begin{array}{l}0.433 \\
(0.493)\end{array}$ & $\begin{array}{l}0.333 \\
(0.638)\end{array}$ & $\begin{array}{l}0.116^{*} \\
(0.127)\end{array}$ & $\begin{array}{l}0.391 \\
(0.819)\end{array}$ \\
\hline Adoption density (OECD region) & $\begin{array}{l}2.077^{* * *} \\
(0.259)\end{array}$ & $\begin{array}{l}1.848^{* * *} \\
(0.281)\end{array}$ & $\begin{array}{l}1.880^{* * *} \\
(0.309)\end{array}$ & $\begin{array}{l}2.835+ \\
(1.690)\end{array}$ & $\begin{array}{l}1.983^{* * *} \\
(0.377)\end{array}$ \\
\hline Electoral democracy & $\begin{array}{l}0.846^{* * *} \\
(0.038) \\
\end{array}$ & $\begin{array}{l}0.899 * * * \\
(0.022)\end{array}$ & $\begin{array}{l}1.002 \\
(0.029) \\
\end{array}$ & $\begin{array}{l}1.082 \\
(0.071)\end{array}$ & $\begin{array}{l}0.987 \\
(0.045)\end{array}$ \\
\hline Observations & 1,012 & 1,153 & 913 & 490 & 1,174 \\
\hline Number of countries & 36 & 36 & 36 & 22 & 36 \\
\hline Number of failures & 26 & 19 & 26 & 15 & 21 \\
\hline Pseudo-R-squared & 0.487 & 0.280 & 0.300 & 0.429 & 0.340 \\
\hline Log likelihood & -38.85 & -40.97 & -51.87 & -18.96 & -38.29 \\
\hline
\end{tabular}

Note: The number of country-day observations varies for each policy since they exit the risk set on the day of adoption. Standard errors in parentheses are clustered at the country level. ${ }^{* * *} \mathrm{p}<0.001,{ }^{* *} \mathrm{p}<0.01,{ }^{*} \mathrm{p}<0.05,+\mathrm{p}<0.10$.

32 Results for "closure of public transportation" were unstable, with control variable included due to only 9 adoption events occurring in the time period studied, and we therefore omitted this policy from the analysis of separate policy adoption. Without control variables, results were similar to those obtained for the other policies, with adoption density (OECD region) strongly predicting a shorter time to adoption, but electoral democracy predicting a longer one. 
The separate event history models in Table B1 show that adoption density in OECD regions strongly predicts the adoption of all types of NPI except for public information campaigns, which are instead predicted by the epidemiological indicator death rate. ${ }^{33}$ The hazard ratios indicate that one additional country in the OECD region adopting the same policy accelerates nearby countries' adoption of school closure by $100 \%$; workplace closure and cancellation of public events by $85 \%$ and $88 \%$ respectively; and restrictions on internal mobility by $98 \%$. Table B1 further reveals that the level of electoral democracy strongly predicts policy adoptions related to school and workplace closures, but not the other interventions. A one percent higher level of electoral democracy decelerates a country's adoption of school or workplace closure interventions by roughly $15 \%$ and $10 \%$, respectively.

\footnotetext{
${ }^{33}$ In a separate analysis (available upon request) we included a period effect corresponding to the World Health Organization's (WHO) global pandemic announcement (March 11, 2020) to control for the potential influence of this announcement on adoption rates. Including the period effect variable did not change any of the main results, but the variable was highly collinear to several of our adoption measures as well as control variables, and we therefore omit it from the main analysis.
} 


\section{Appendix C: Variable descriptive, stringency post-hoc test (Table 3)}

Table C1: GLS descriptive statistics and correlation matrix

\begin{tabular}{|c|c|c|c|c|c|c|c|c|}
\hline & & Mean & S.D. & Min & Max & 1 & 2 & 3 \\
\hline 1 & Stringency index & 31.895 & 28.204 & 0 & 100 & & & \\
\hline 2 & GDP per capita (log) & 10.592 & 0.511 & 9.145 & 11.667 & -0.092 & & \\
\hline 3 & Tax revenue ( $\%$ of GDP) & 19.343 & 5.878 & 9.633 & 33.369 & -0.039 & 0.115 & \\
\hline 4 & GINI index (income) & 32.985 & 4.526 & 24.200 & 45.4 & 0.014 & -0.316 & -0.337 \\
\hline 5 & Hospital beds (/1,000 people) & 5.226 & 3.071 & 1.500 & 13.4 & 0.122 & -0.088 & -0.318 \\
\hline 6 & Population age $\geq 65(\%)$ & 18.284 & 3.975 & 7.224 & 27.576 & -0.096 & 0.140 & -0.019 \\
\hline 7 & Urban population $(\%)$ & 80.848 & 9.549 & 53.726 & 98.001 & -0.049 & 0.356 & 0.108 \\
\hline 8 & Population density (log) & 4.332 & 1.505 & 1.178 & 6.272 & 0.277 & -0.161 & -0.078 \\
\hline 9 & Death rate $\left(/ 100^{\prime}\right)$ & 0.180 & 0.832 & 0 & 13.979 & 0.332 & 0.040 & 0.007 \\
\hline 10 & Infection rate (/100’) & 10.057 & 29.176 & 0 & 325 & 0.255 & 0.250 & 0.096 \\
\hline \multirow[t]{2}{*}{11} & Electoral democracy & 82.554 & 9.188 & 29.200 & 90 & -0.223 & 0.547 & 0.124 \\
\hline & & 4 & 5 & 6 & 7 & 8 & 9 & 10 \\
\hline 1 & Stringency index & & & & & & & \\
\hline 2 & GDP per capita (log) & & & & & & & \\
\hline 3 & Tax revenue ( $\%$ of GDP) & & & & & & & \\
\hline 4 & GINI index (income) & & & & & & & \\
\hline 5 & Hospital beds (/1,000 people) & -0.283 & & & & & & \\
\hline 6 & Population age $\geq 65(\%)$ & -0.432 & 0.476 & & & & & \\
\hline 7 & Urban population $(\%)$ & -0.026 & 0.032 & 0.009 & & & & \\
\hline 8 & Population density (log) & -0.030 & 0.505 & 0.213 & 0.004 & & & \\
\hline 9 & Death rate $\left(/ 100^{\prime}\right)$ & -0.002 & -0.063 & 0.036 & 0.026 & 0.095 & & \\
\hline 10 & Infection rate $\left(/ 100^{\prime}\right)$ & -0.110 & -0.058 & -0.092 & 0.081 & -0.014 & 0.545 & \\
\hline 11 & Electoral democracy & -0.379 & 0.011 & 0.390 & 0.160 & -0.111 & 0.087 & 0.108 \\
\hline
\end{tabular}




\section{Appendix D: Robustness tests of Tables 2 and 3, infection rate instead of death rate}

Table D1. Marginal risk set models (infection rate)

\begin{tabular}{lllll}
\hline & $(1)$ & $(2)$ & $(3)$ & $(4)$ \\
\hline GDP per capita (log) & 0.292 & $0.247 *$ & 0.720 & 0.744 \\
Tax revenue (\% of GDP) & $(0.252)$ & $(0.136)$ & $(0.743)$ & $(0.729)$ \\
& 1.001 & 0.965 & 0.995 & 0.963 \\
GINI index (income) & $(0.053)$ & $(0.052)$ & $(0.051)$ & $(0.060)$ \\
& $0.840^{* *}$ & $0.830^{* *}$ & $0.816^{* *}$ & $0.777^{* * *}$ \\
Hospital beds (/1,000 people) & $(0.052)$ & $(0.055)$ & $(0.056)$ & $(0.057)$ \\
& $0.760^{*}$ & $0.730^{*}$ & $0.753 *$ & $0.722^{*}$ \\
Population age $\geq 65(\%)$ & $(0.102)$ & $(0.100)$ & $(0.096)$ & $(0.102)$ \\
& 0.871 & 0.875 & 0.944 & 0.918 \\
Urban population (\%) & $(0.092)$ & $(0.074)$ & $(0.087)$ & $(0.094)$ \\
& 0.975 & 0.994 & 0.976 & 0.976 \\
Population density (log) & $(0.028)$ & $(0.028)$ & $(0.028)$ & $(0.028)$ \\
Infection rate (/100') & $1.857 * *$ & $1.938^{* * *}$ & $1.940 * * *$ & $1.868^{* * *}$ \\
Adoption density (OECD region) & $(0.362)$ & $(0.329)$ & $(0.351)$ & $(0.306)$ \\
& 0.976 & & & $0.923 *$ \\
Electoral democracy & $(0.020)$ & & & $(0.034)$ \\
& & $1.302^{* * *}$ & & $1.495^{* * *}$ \\
\hline Observations & & $(0.087)$ & & $(0.135)$ \\
Number of countries & & & $0.921^{* *}$ & $0.939+$ \\
Number of failures & 5,278 & 5,278 & $(0.029)$ & $(0.034)$ \\
Pseudo-R-squared & 36 & 36 & 5,278 & 5,278 \\
Log likelihood & 138 & 138 & 36 & 36 \\
\hline
\end{tabular}


Table D2. Stringency of Adopting Covid-19 NPIs (infection rate)

\begin{tabular}{|c|c|c|c|}
\hline & (1) & (2) & (3) \\
\hline \multirow[t]{2}{*}{ GDP per capita (log) } & -9.655 & 4.445 & -2.735 \\
\hline & $(6.898)$ & $(6.759)$ & $(6.848)$ \\
\hline \multirow[t]{2}{*}{ Tax revenue ( $\%$ of GDP) } & -0.302 & -0.162 & -0.339 \\
\hline & $(0.618)$ & $(0.541)$ & $(0.595)$ \\
\hline \multirow[t]{2}{*}{ GINI index (income) } & -0.687 & -0.815 & -0.723 \\
\hline & $(0.802)$ & $(0.601)$ & $(0.761)$ \\
\hline \multirow[t]{2}{*}{ Hospital beds (/1,000 people) } & -0.407 & -0.424 & -0.821 \\
\hline & $(1.470)$ & $(1.314)$ & $(1.481)$ \\
\hline \multirow[t]{2}{*}{ Population age $\geq 65(\%)$} & -0.884 & -0.711 & -0.008 \\
\hline & $(0.742)$ & $(0.754)$ & $(0.794)$ \\
\hline \multirow[t]{2}{*}{ Urban population (\%) } & 0.060 & 0.046 & 0.047 \\
\hline & $(0.294)$ & $(0.253)$ & $(0.270)$ \\
\hline \multirow[t]{2}{*}{ Population density (log) } & $6.394 *$ & $5.905^{* * *}$ & $5.770^{*}$ \\
\hline & $(2.682)$ & $(1.792)$ & $(2.521)$ \\
\hline \multirow[t]{2}{*}{ Infection rate $\left(/ 100^{\prime}\right)$} & $0.399 *$ & & $0.397 *$ \\
\hline & $(0.168)$ & & $(0.168)$ \\
\hline \multirow[t]{2}{*}{ Electoral democracy } & & $-0.709 * * *$ & $-0.716^{* *}$ \\
\hline & & $(0.193)$ & $(0.224)$ \\
\hline \multirow[t]{2}{*}{ Constant } & 142.381 & 58.126 & 119.943 \\
\hline & $(90.725)$ & $(76.766)$ & $(86.582)$ \\
\hline Observations & 1,356 & 1,356 & 1,356 \\
\hline Number of countries & 36 & 36 & 36 \\
\hline Overall R-square & 0.167 & 0.128 & 0.188 \\
\hline
\end{tabular}

\section{Appendix E: Post-hoc test: effects of elements of democracy on policy adoption}

Figure E1. Marginal risk set models, various elements of democracy

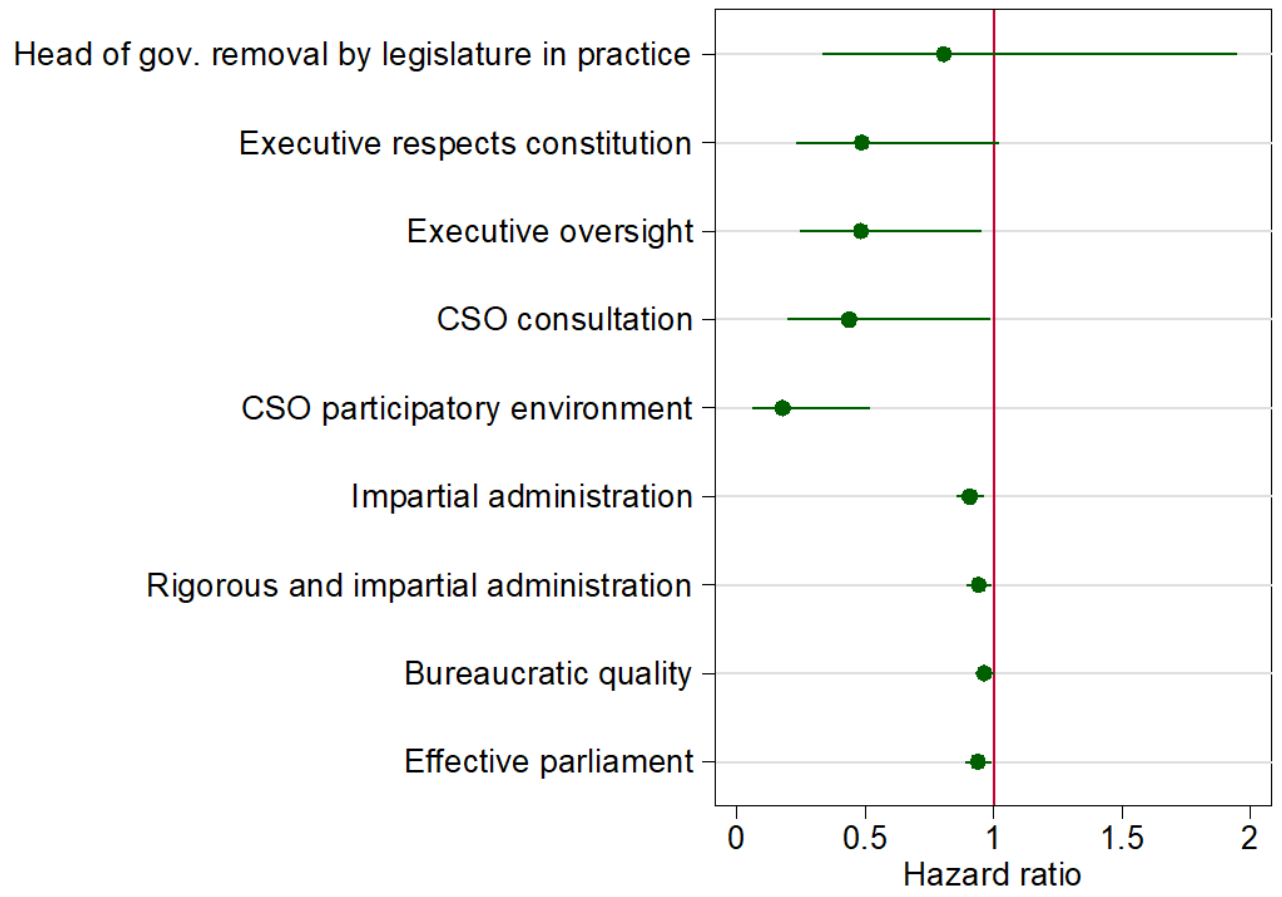


Figure E2. Effects of proximate countries' policy adoption on the probability of countries with lower or higher levels of 'rigorous and impartial administration' (RIA) adopting Covid-19 policies

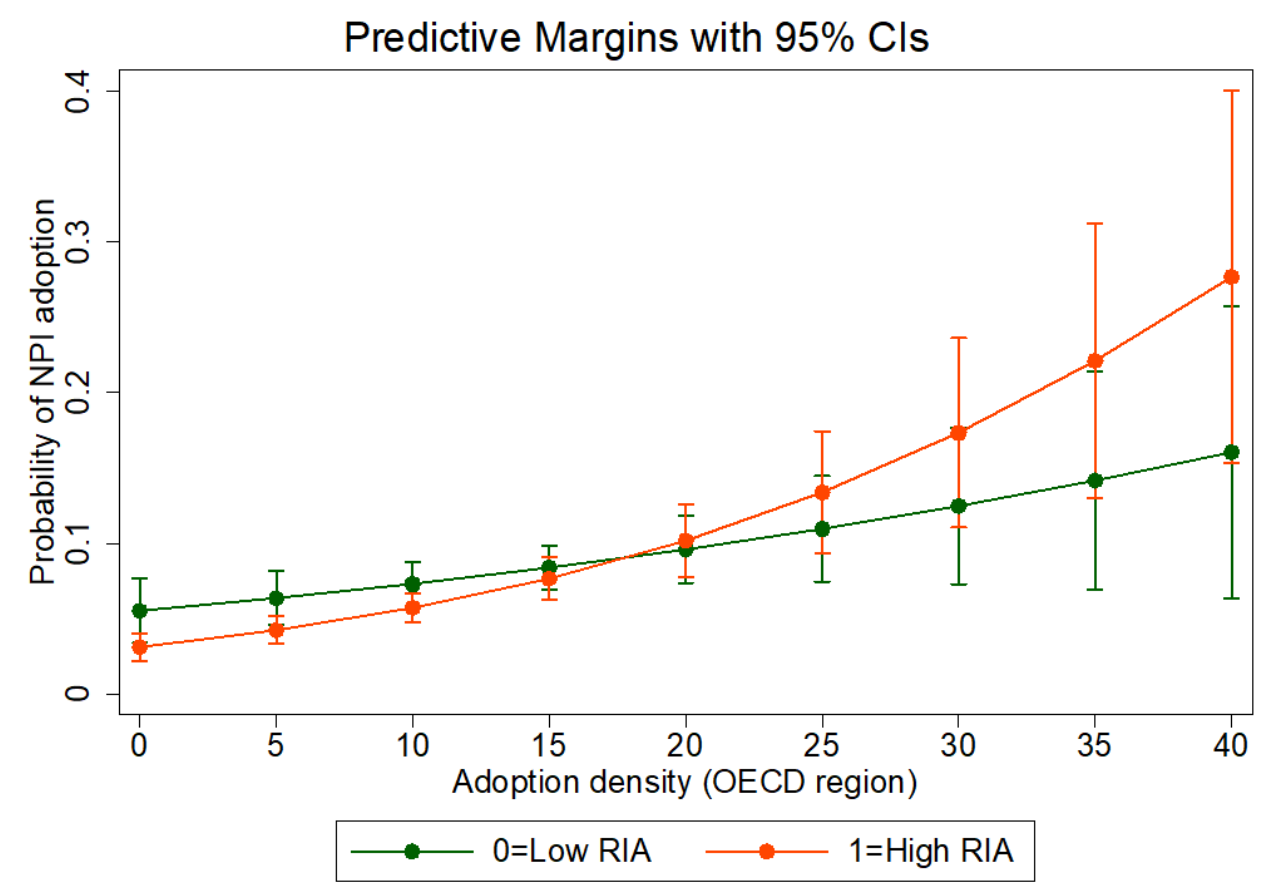

